\title{
The Genetic Basis of the Polycystic Ovary Syndrome: A Literature Review Including Discussion of PPAR- $\gamma$
}

\author{
Ugur Unluturk, ${ }^{1}$ Ayla Harmanci, ${ }^{1,2}$ Cetin Kocaefe, ${ }^{3}$ and Bulent O. Yildiz ${ }^{1,2}$ \\ ${ }^{1}$ Department of Internal Medicine, Faculty of Medicine, Hacettepe University, Hacettepe, 06100 Ankara, Turkey \\ ${ }^{2}$ Endocrinology and Metabolism Unit, Faculty of Medicine, Hacettepe University, Hacettepe, 06100 Ankara, Turkey \\ ${ }^{3}$ Department of Medical Biology, Faculty of Medicine, Hacettepe University, Hacettepe, 06100 Ankara, Turkey
}

Received 19 July 2006; Revised 24 November 2006; Accepted 3 December 2006

Recommended by Carolyn M. Komar

Polycystic ovary syndrome (PCOS) is the most common endocrine disorder of the women of reproductive age. Familial clustering of PCOS has been consistently reported suggesting that genetic factors play a role in the development of the syndrome although PCOS cases do not exhibit a clear pattern of Mendelian inheritance. It is now well established that PCOS represents a complex trait similar to type-2 diabetes and obesity, and that both inherited and environmental factors contribute to the PCOS pathogenesis. A large number of functional candidate genes have been tested for association or linkage with PCOS phenotypes with more negative than positive findings. Lack of universally accepted diagnostic criteria, difficulties in the assignment of male phenotype, obscurity in the mode of inheritance, and particularly small sample size of the study populations appear to be major limitations for the genetic studies of PCOS. In the near future, utilizing the genome-wide scan approach and the HapMap project will provide a stronger potential for the genetic analysis of the syndrome.

Copyright $\odot 2007$ Ugur Unluturk et al. This is an open access article distributed under the Creative Commons Attribution License, which permits unrestricted use, distribution, and reproduction in any medium, provided the original work is properly cited.

\section{INTRODUCTION}

PCOS is a highly prevalent endocrine disorder affecting approximately $7 \%$ of reproductive-aged women [1]. There is no consensus on the diagnostic criteria and definition of PCOS. The most widely used 1990 National Institute of Child Health and Human Development (NICHD) conference diagnostic criteria include (i) clinical and/or biochemical signs of hyperandrogenism, (ii) oligo-ovulation, and (iii) exclusion of other known disorders such as Cushing's syndrome, hyperprolactinemia and nonclassic adrenal hyperplasia [2]. A recent expert meeting sponsored by European Society of Human Reproduction and Embryology (ESHRE)/American Society for Reproductive Medicine (ASRM) suggested that the definition of PCOS should include two of the following three criteria: (i) oligo- and/or anovulation, (ii) clinical and/or biochemical signs of hyperandrogenism, (iii) polycystic ovaries on ultrasonography, and exclusion of related disorders [3, 4].

Patients with PCOS have several interrelated characteristics including hyperandrogenism, altered gonadotropin dynamics, chronic anovulation, polycystic ovaries, and insulin resistance. The syndrome has a significant reproductive and metabolic impact, and is associated with increased risk of type-2 diabetes, dyslipidemia, cardiovascular disease (CVD), and endometrial carcinoma [5-7]. Overall, PCOS can be viewed as a heterogeneous androgen excess disorder with varying degrees of gonadotropic and metabolic abnormalities. Development of PCOS may require the interaction of multiple inherited and environmental factors. Herein, we will briefly overview the available evidence regarding the genetic basis of PCOS.

\section{FAMILIAL AGGREGATION OF THE SYNDROME}

The familial aggregation of PCOS phenotypes and of associated metabolic and reproductive abnormalities has been long noted [8]. While clustering of cases in families strongly support the role of genetic factors in the development of PCOS, heterogeneity of phenotypic features in different families and even within the same family underscores the importance of the environmental contribution. PCOS appears to be a common and complex trait and the exact pattern of inheritance is yet to be fully explained $[22,23]$. Family studies of PCOS investigated mainly ovarian morphology, menstrual irregularities, symptoms of hyperandrogenism and 
TABLE 1: Summary of the studies of familial aggregation in PCOS.

\begin{tabular}{|c|c|c|c|}
\hline Suggested inheritance & Diagnostic criteria & $\begin{array}{l}\text { Phenotype in } \\
\text { first-degree relatives }\end{array}$ & References \\
\hline $\begin{array}{l}\text { Autosomal dominant with } \\
\text { variable penetrance }\end{array}$ & $\begin{array}{l}\text { Oligomenorrhea, hirsutism, } \\
\text { and }{ }^{(a)} \text { PCO }\end{array}$ & $\begin{array}{l}\text { Women: oligomenorrhea } \\
\text { and PCO }\end{array}$ & Cooper et al. [8] \\
\hline X-linked & $\begin{array}{l}\text { Oligomenorrhea, hirsutism, } \\
\text { and PCO }\end{array}$ & $\begin{array}{l}\text { Women: hyperandrogenism } \\
\text { and metabolic disorders } \\
\text { Men: oligospermia } \\
\text { and LH hypersecretion }\end{array}$ & Givens et al. $[9,10]$ \\
\hline Not determined & $\begin{array}{l}\text { Hirsutism and/or } \\
\text { oligomenorrhea }\end{array}$ & $\begin{array}{l}\text { Women: infertility, } \\
\text { oligomenorrhea, } \\
\text { and hirsutism }\end{array}$ & Ferriman and Purdie [11] \\
\hline Autosomal dominant & $\begin{array}{l}\text { Menstrual dysfunction, } \\
\text { hyperandrogenism, obesity, } \\
\text { infertility, and PCO }\end{array}$ & $\begin{array}{l}\text { Women: hyperandrogenic } \\
\text { symptoms } \\
\text { Men: premature baldness } \\
\text { and increased hairiness }\end{array}$ & Lunde et al. [12] \\
\hline Not determined & $\begin{array}{l}\text { Menstrual irregularities, } \\
\text { hirsutism, infertility, } \\
\text { PCO, and obesity }\end{array}$ & Women: PCO & Hague et al. [13] \\
\hline Monogenic & PCO & $\begin{array}{l}\text { Women: } \mathrm{PCO} \\
\text { Men: premature baldness }\end{array}$ & Carey et al. [14] \\
\hline Not determined & $\begin{array}{l}\text { Elevated androgens, } \\
\text { decreased SHBG, and PCO }\end{array}$ & $\begin{array}{l}\text { Men: premature baldness, } \\
\text { hypertriglyceridemia, } \\
\text { and hyperinsulinemia }\end{array}$ & Norman et al. [15] \\
\hline Not determined & NICHD & Women: Beta-cell dysfunction & Colilla et al. [16] \\
\hline Monogenic & NICHD & $\begin{array}{l}\text { Women: PCOS (NICHD), } \\
\text { hyperandrogenemia, } \\
\text { and insulin resistance }\end{array}$ & Legro et al. [17-19] \\
\hline Not determined & NICHD & Women: PCOS (NICHD) & Kahsar-Miller et al. [20] \\
\hline Not determined & NICHD & $\begin{array}{l}\text { Women: PCOS (NICHD) } \\
\text { and insulin resistance } \\
\text { Men: insulin resistance }\end{array}$ & Yildiz et al. [21] \\
\hline
\end{tabular}

${ }^{(a)}$ PCO: polycystic ovaries.

hyperandrogenemia $[11-14,17,20,22,24]$. The results of these studies are summarized in Table 1.

Cooper et al., in their large study, first described that the incidence of oligomenorrhea and polycystic ovaries is increased in first-degree relatives of PCOS patients compared with the controls [8]. Although male relatives were not specifically studied, a questionnaire revealed that they were noted to have increased pilosity. Additionally, in this study the proposed mechanism of inheritance was autosomal dominant with decreased penetrance [8].

Givens et al. have reported a series of family-based studies, using as diagnostic criteria consisting of hirsutism, oligomenorrhea, and enlarged ovaries $[9,10]$. They found familial aggregation of hyperandrogenic and metabolic disorders. These studies were the first to reveal some of the severe metabolic sequelae, such as diabetes mellitus, insulin resis- tance, lipid abnormalities, hypertension, and arteriosclerosis. They also underscored the variability of phenotype in PCOS, even within the same kindred. Oligospermia and increased LH secretion were found in some of the male subjects of the study participants, suggesting an X-linked pattern of inheritance $[9,10]$.

Hague et al. utilized high-resolution ultrasonography to identify polycystic ovaries in 61 women with menstrual disturbances, hyperandrogenism, obesity, and infertility as well as in their first-degree female relatives [13]. They found that $67 \%$ of the mothers and $87 \%$ of the sisters of probands were affected [13]. In this study no attempt was made to identify a male phenotype.

Ferriman and Purdie studied a large group of hirsute women with and without oligomenorrhea and their families [11]. They reported a higher prevalence of hirsutism, 
oligomenorrhea and infertility in first-degree relatives compared with nonhirsute control women. A questionnaire revealed an increased baldness in male relatives [11]. Affected female and male family members were not systematically characterized in this study.

Lunde et al. studied families of 132 Norwegian women identified on the basis of an ovarian wedge resection, who also had two or more of the following symptoms: menstrual irregularity, hirsutism, infertility, and/or obesity [12]. They also compared these women with controls and their families, and found a significantly higher percentage of PCOS-related symptoms in the first-degree female relatives of PCOS patients and observed a significantly higher percentage of premature balding and increased pilosity among male relatives [12].

Using NICHD criteria for the diagnosis of PCOS, KahsarMiller et al. reported the rates of PCOS in mothers and sisters of patients with PCOS as $24 \%$ and $32 \%$, respectively [20]. Legro et al. showed that $22 \%$ of reproductive aged sisters of women with PCOS fulfilled the diagnostic criteria of PCOS, whereas $24 \%$ had increased $T$ and DHEAS values with regular menstrual cycles [17]. We have reported $16 \%$ and $8 \%$ PCOS prevalence rates in sisters and mothers of Turkish PCOS patients, respectively [21].

Recently, quantitative phenotypes related to hyperandrogenemia and glucose homeostasis are also shown to be heritable in PCOS. Evidence for heritability of metabolic phenotypes such as beta cell function and insulin resistance was reported in family studies of PCOS. Studying the families of five patients with PCOS, Norman et al. reported that increased insulin levels were common among first-degree relatives [15]. Colilla et al. noted that there was a heritable component of beta cell dysfunction in families of women with PCOS [16]. Legro et al. reported that affected sisters of women with PCOS (who fulfill criteria for the diagnosis of PCOS, and those with hyperandrogenemia) had high insulin levels and low fasting glucose to insulin ratios [18], and the brothers of women with PCOS had increased dehydroepiandrosterone (DHEAS) levels [19]. We have reported that mothers and fathers of PCOS patients have increased prevalence of glucose intolerance and type- 2 diabetes whereas brothers and sisters show insulin resistance compared to age- and BMI-matched healthy controls [21].

\section{METHODS USED IN GENETIC STUDIES OF PCOS}

Two mainstream approaches employed to identify a genetic locus for PCOS are (i) association studies where a predisposing allele is expected to be encountered more frequently in the effected population than the normal individuals and (ii) linkage studies where the probands and their families are investigated to determine if particular genomic landmarks are distributed independently or in linkage (together) with the phenotype. While the mode of inheritance is not required for the association studies, it requires that a relatively large set of individuals are needed for a clear conclusion. The canonical linkage studies require that the mode of inheritance should be known for the analysis procedure. These studies are quite robust to identify single genes causing Mendelian disorders but are poorly suited to the genetic architecture of complex traits such as PCOS. The variable penetrance and expressivity are two main factors that are complicating both association and linkage methods (reviewed in [25]).

The frequency of the genomic landmarks used in linkage studies defines the resolution and the mapping power of the study. The whole genome scan approach utilizing the SNP (single nucleotide polymorphism) microarray genechip technology brings the highest resolution in genetic mapping [26]. Yet, there is no PCOS study published with this technique. Furthermore the HapMap project brings further power to association studies by genotyping over a million SNPs and characterizing genetic variation patterns in linkage disequilibrium [27].

\section{CANDIDATE GENES IN PCOS}

\subsection{Genes involved in ovarian and adrenal steroidogenesis}

The most common biochemical abnormality in women with PCOS is hyperandrogenemia (Figure 1). For this reason, researchers have long been trying to find a linkage or an association between PCOS and the genes involved in the androgen biosynthetic pathway. The most relevant genes involved in steroidogenesis, CYP11a, CYP21, CYP17, and CYP19, along with their controversial properties are discussed below.

\subsubsection{CYP11a}

Adrenal and ovarian steroidogenesis start with the conversion of cholesterol into progesterone, which is catalyzed by the P450 cytochrome side chain cleavage enzyme encoded by CYP11a located at 15q24 [28]. This conversion is a rate limiting step of steroidogenesis. Gharani et al. conducted an association study of 97 women with PCOS and showed a significant association between serum testosterone levels and the alleles of the CYP11a with a $5^{\prime}$ untranslated region (UTR) consisting of repeats of a $(\mathrm{tttta})_{n}$ pentanucleotide, a VNTR (variable number tandem repeat) polymorphism [29]. Two independent case-control studies from Greece [30] and China [31], respectively, confirmed these findings in support of the encouraging evidence for the association between CYP11a and PCOS.

Although these studies proposed that allelic variants of CYP1la have a role in the etiology of hyperandrogenemia and/or PCOS, subsequent studies including one with a very large sample size from United Kingdom and Finland [32] have failed to find a significant linkage or association between this gene locus and/or its VNTR alleles and PCOS [32-36].

Above all, CYP11a, with its associated polymorphisms, remains, at least in part, a potential candidate gene for the pathogenesis of PCOS, and further investigations are required due to these controversial results. 


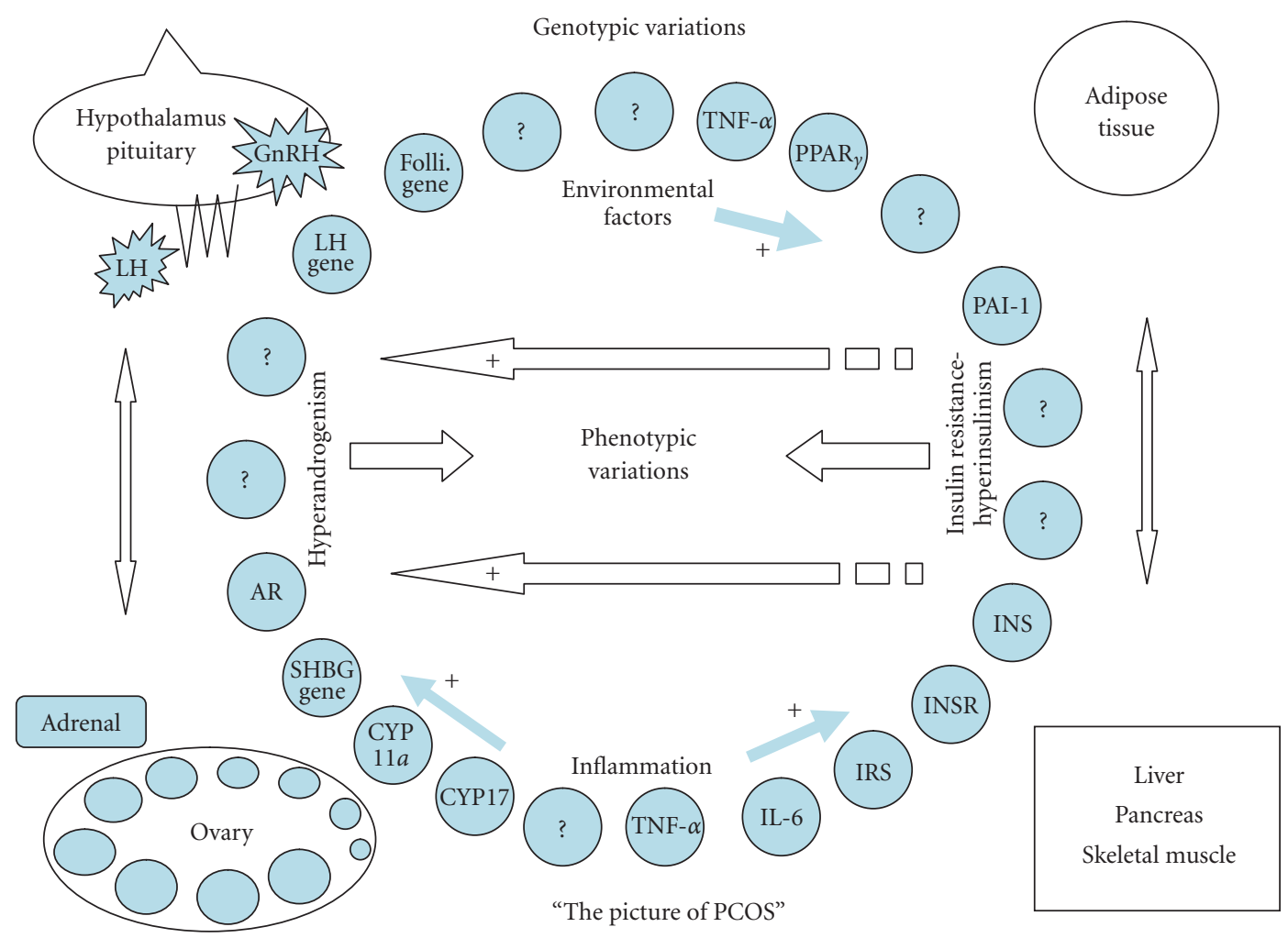

FIGURE 1: PCOS is a complex genetic syndrome. A dysregulation of androgen synthesis plays a key role in the pathogenesis of PCOS. This dysregulation may be triggered by genomic variants related to hyperandrogenism and environmental factors, such as sedentary life-style and dietary habits. The hyperandrogenemic condition causes follicles not to grow as much as dominant follicle and leads oligo/anovulation. The progesterone peak does not occur through luteal phase of menstrual cycle, and the frequency and amplitude of GnRH pulses are increased, which in turn cause the secretion of LH to increase. By means of increasing LH levels, androgen synthesis and secretion are stimulated in the ovaries and adrenals. On the other hand, the inherited insulin resistance leads a hyperinsulinemic condition causing androgen synthesis to increase and SHBG synthesis to decrease. Additionally, obesity that is inherited and/or acquired could cause a chronic inflammation via secreting inflammatory cytokines from adipose tissue, which stimulates androgen sythesis and increases insulin resistance. As a consequence, interactions among ovary, hypothalamus-pituitary, adrenal, adipose tissue, liver, skeletal muscle and $\tilde{\beta}$-cells of pancreas draw the picture of PCOS. Environmental factors and genetic variations constitute the phenotypic variability/colors of the picture.

\subsubsection{CYP21}

One of the main steps in adrenal and ovarian steroidogenesis is the conversion of 17-hydroxyprogesterone into 11-deoxycortisol, which is catalyzed by the 21-hydroxylase enzyme encoded by CYP21. The deficiency of this enzyme, which is inherited by an autosomal recessive trait, is responsible for most cases of congenital adrenal hyperplasia, and increased serum 17-hydroxyprogesterone levels are correlated with its deficiency. Women with functional hyperandrogenism or PCOS have an increased serum 17hydroxyprogesterone response to ACTH stimulation as a common finding $[37,38]$. Furthermore, patients having both heterozygote CYP21 mutations and clinical symptoms exhibit a PCOS-like phenotype [39]. Accordingly, mutations of CYP21 have been investigated as a candidate gene in patients with PCOS. Witchel et al. showed that children with premature pubarche and adolescent girls with hyperandrogenism were heterozygous for mutations in CYP21 [39, 40]. However, Escobar-Morreale et al. found no clear concordance between the CYP21 genotype and the functional origin of androgen excess [41] and Glintborg et al. could not find such a concordance in women with idiopathic hirsutism and PCOS [42]. More recently, Witchel et al. conducted a case-control study of 114 PCOS patients, which indicated no significant differences in the allele frequency of CYP21 mutations between PCOS patients with and without androgen excess and controls [43]. Overall, CYP21 and associated mutations seem not to play a key role in the development of PCOS.

\subsubsection{CYP17}

Other rate limiting steps of adrenal and ovarian androgen biosynthesis are the conversion of pregnenolone and progesterone into 17-hydroxypregnenolone and 17hydroxyprogesterone, respectively, and of these steroids into dehydro-epiandrosterone and androstenedione, which is catalyzed by the P450c17 $\alpha$ enzyme. This enzyme has both $17 \alpha$-hydroxylase and 17,20-lyase activities and is encoded 
by CYP17 located at 10q24.3 [44, 45]. It was initially proposed that an exaggerated adrenal and ovarian responsiveness and increased P450c17 $\alpha$ enzyme activity were responsible for enhanced androgen levels in patients with PCOS and functional hyperandrogenism [46, 47]. Escobar-Morreale et al. also suggested that most of the hyperandrogenic women have increased $\mathrm{P} 450 \mathrm{c} 17 \alpha$ activity in adrenal and ovarian sites $[37,48]$. In accordance with these studies, Wickenheisser et al. reported increased $\mathrm{P} 450 \mathrm{c} 17 \alpha$ expression and enzymatic activity in ovarian theca cells from women with PCOS as well as increased transactivation of the CYP17 promoter $[49,50]$. Moreover, they reported for the first time that CYP17 expression is dysregulated at the level of mRNA stability in PCOS theca cells [51].

In another study, Carey et al. identified a rare $\mathrm{T} / \mathrm{C}$ single nucleotide polymorphism (SNP) in the promoter region of CYP17 increasing the susceptibility to develop PCOS [52]. Even though Diamanti-Kandarakis et al. confirmed this finding in Greek patients with PCOS [53], subsequent more comprehensive studies have failed to detect a significant linkage or association between CYP17 and PCOS [35, 54-58].

Although the available evidence suggests that CYP17 is not a strong candidate gene for PCOS, we should also note that posttranslational regulation of this gene product might play a role in the pathophysiology of PCOS. Because serine phosphorylation is involved in the posttranslational regulation of 17,20-lyase activity [59], it was proposed that posttranscriptional hyperphosphorylation of the serine residues of P $450 \mathrm{c} 17 \alpha$ by a defective serine kinase might increase the 17,20 -lyase activity of this enzyme $[59,60]$. Interestingly, it was demonstrated that serine phosphorylation of the $\beta$ chain of the insulin receptor causes insulin resistance in vitro $[61,62]$. Another interesting finding is that $50 \%$ of PCOS women who had both hyperandrogenism and insulin resistance had hyperphosphorylated serine residues on their insulin receptors [63]. Therefore, that a single defect produces both the insulin resistance and the hyperandrogenism in some of the PCOS women was postulated [64]. Altogether, these data provide an encouraging evidence to support the serine kinase hypothesis of PCOS; however, this hypothesis is still to be proved.

\subsubsection{CYP19}

An enzyme complex, called aromatase, converts C19 steroids (androgens) to C18 steroids (estrogens). This enzyme complex is composed of the cytochrome P450 aromatase (P450arom) and the NADPH cytochrome $\mathrm{P} 450$ reductase [65], and P450arom is encoded by CYP19 located at 15p21.1 $[66,67]$. Aromatase deficiency has been reported in a number of hyperandrogenic patients $[68,69]$. Immunohistochemical studies of polycystic ovaries could not reveal any aromatase activity in antral follicles of various sizes [70]. Erickson et al. demonstrated that granulosa cells obtained from medium-sized follicles of women with PCOS have little aromatase activity [71]. Similarly, Jakimiuk et al. showed that when compared to the control follicles, all PCOS follicles contained low levels of P450arom mRNA, estradiol, and lower aromatase stimulating bioactivity [72]. These findings indicate that the aromatase activity might be decreased in follicles from patients with PCOS, and that the possible androgen excess resulting from this decreased activity might contribute to abnormal follicle development. Whether the CYP19 is a candidate gene for the pathogenesis of PCOS or of hyperandrogenism has, therefore, been investigated. Linkage and mutation screening studies did not reveal any evidence that variation at the CYP19 locus participates in the etiology of PCOS [29, 35, 73]. However, association studies utilizing SNPs and haplotypes showed association with PCOS symptom score and serum testosterone levels $[74,75]$.

\subsection{Genes involved in steroid hormone effects}

\subsubsection{Androgen receptor gene}

All androgens operate through the androgen receptor and this receptor belongs to a family of nuclear transcription factors. The androgen receptor is encoded by a gene (AR) located at Xq11-12 [76] and is composed of three functional domains: the transactivation domain, the DNA binding domain, and the ligand-binding domain. A VNTR polymorphism consisting of CAG repeats (from 11 to 38 repeats, an average of 20) in exon-1, encoding a polyglutamine chain in the $N$-terminal transactivation domain, is embedded in AR [77]. The transcriptional activity of androgen receptor is inversely correlated with the number of CAG repeats [78]. Variations of these repeats, even within the normal polymorphic range (11-38 CAGs), have been related to various disorders associated with low- or high-androgenic activities [7982]. Therefore, decreased number of CAG repeats with an increased androgen receptor activity could explain some of the PCOS phenotype exhibiting the normal serum androgen levels and hyperandrogenism symptoms [83]. Nevertheless, Urbanek et al. could not find any association between this VNTR and PCOS [35]. Similarly, Mifsud et al. found no differences between the anovulatory PCOS patients and controls for the distribution of the CAG repeats [83]. On the contrary, Hickey et al. demonstrated a significantly greater frequency of alleles with longer CAG repeats ( $>22$ repeats) for infertile PCOS patients compared with fertile women [84]. Indeed, both of these studies indicated an association between the testosterone levels and CAG repeats in AR, albeit with different results. Confirming the reports of Urbanek et al. [35] and Mifsud et al. [83], in a more recent study conducted in Finland, Jääskeläinen et al. reported that CAG repeats of AR are not the major determinants of PCOS [85]. They also found no correlation between this VNTR and body mass index or serum testosterone levels [85]. As a result, no convincing evidence exists about the role of AR in the pathogenesis of PCOS.

\subsubsection{Sex hormone-binding globulin gene}

SHBG regulates the access of androgens to target tissues. Serum SHBG levels are commonly low in patients with hyperandrogenism, especially in association with PCOS, which 
contributes to increased tissue androgen availability [86]. Human SHBG is composed of a homodimeric glycoprotein produced by hepatocytes and is encoded by a $4-\mathrm{kb}$ gene at the $17 \mathrm{p} 12-\mathrm{p} 13[87,88]$. A pentanucleotide repeat polymorphism, (TAAAA) $n$, at the promoter of human $S H B G$ gene has been described [89]. This polymorphism has also been demonstrated to influence the transcriptional activity of SHBG gene [89]. Under the light of these data, it has been proposed that this functional polymorphism could contribute to individual diversities in plasma SHBG levels and thus influence the access of androgens to target tissues [90]. For this reason, Xita et al. investigated whether the (TAAAA) $_{n}$ polymorphism of the SHBG gene is associated with PCOS and whether polymorphic variants of the gene are related to serum SHBG levels in women with PCOS. They reported a significant association between this repeat polymorphism and PCOS in a Greek population [90]. In this study, PCOS patients were frequently carrying more than 8 repeats while nonhyperandrogenic controls presented with a higher frequency of alleles carried fewer than 8 repeats. Besides, PCOS patients carrying the longer allele genotypes had lower SHBG levels [90]. In accordance with the latter result, Cousin et al. recently demonstrated in hirsute women that longer (TAAAA) ${ }_{n}$ alleles caused serum SHBG levels to be decreased when compared with six repeat alleles [91]. They also identified that an SNP (Asp327Asn) in exon 8 of the SHBG gene increases the SHBG half-life as well as having a strong disequilibrium linkage with the eight (TAAAA) ${ }_{n}$ polymorphism [91]. Although Urbanek et al. could not find any association or linkage between a marker close to the SHBG locus and PCOS [35], based on the available evidence it could be concluded that $S H B G$ gene is a potential candidate gene in the pathogenesis of PCOS.

\subsection{Genes involved in gonadotropin action and regulation}

\subsubsection{LH and its receptor genes}

Both increased LH levels and altered LH action are frequently observed in PCOS patients, and these abnormalities are associated with anovulation through, at least in part, an adverse effect of LH on oocyte maturation $[92,93]$. Therefore, the gene encoding the $\beta$-subunit of $\mathrm{LH}$, responsible for $\mathrm{LH}$ specificity, has been explored in PCOS patients.

Initially, an immunologically abnormal form of LH with two-point mutations, Trp8Arg and Ilg15Thr, in the LH $\beta$ subunit gene was identified [94]. Afterwards, it was demonstrated that these mutations are universally common polymorphisms with $15 \%$ prevalence worldwide [95]. In addition, these mutations produced structural changes in the variant LH molecules (v-LH) [96] and caused v-LH to have an increased in vitro activity and a decreased in vivo half life compared to that of nonmutant form [97]; however, in vivo activity of v-LH could not be explained. In order to understand the relevance of $\mathrm{v}-\mathrm{LH}$ in patients with PCOS, Rajkhowa et al. explored the implication of v-LH in both healthy women and PCOS patients and found that the occurrence of these mutations in $L H \beta$-subunit gene was not higher in PCOS compared with healthy women [98]. On the other hand, subgroup analysis of this study revealed that obese PCOS patients had a higher frequency of the heterozygous vLH compared with the obese controls [98]. Contrary to the latter finding, Tapanainen et al. in their multicenter study reported that the obese PCOS patients from the Netherlands, Finland, and the United States, but not from the United Kingdom have a lower frequency of this variant form [99]. Although this finding suggests that v-LH somehow protects obese women from developing PCOS, other studies failed to find any association with PCOS $[95,100,101]$.

Another identified variant form of $\mathrm{LH}$ was due to a single missense mutation, Gly102Ser, in the $L H \beta$-subunit gene [102]. Ramanujam et al. studied this mutation in 176 patients with menstrual disorders and 200 normal ovulatory Singapore Chinese women and found it present in only seven patients with menstrual disorders [100]. Recently, Takahashi et al. demonstrated that numerous SNPs in the promoter region of the $L H \beta$-subunit gene were more frequent in patients with ovulatory disorders including PCOS than normal ovulatory women [103].

The hypothesis that an activating mutation in the $L H$ receptor gene might be a cause of hyperandrogenism in patients with PCOS having normal serum LH concentrations and raised androgen levels was tested using linkage analysis in families with multiple cases of PCOS, and five families in whom polymorphic markers close to the $L H$ receptor gene segregate with the syndrome were identified [104]. Nevertheless, in a subsequent preliminary study, these authors did not find any mutations after gene sequencing in these affected families [104]. Likewise, Urbanek et al. reported negative results in their study in which total of 37 potential candidate genes were examined in 150 families with PCOS [35].

In summary, the functional effects of these $\mathrm{v}$-LHs remain unclear and seem not to play a key role in PCOS pathogenesis or female infertility, but further studies are required to determine the physiological and pathophysiological significance of this LH variant.

\subsubsection{Follistatin gene}

Follistatin, a monomeric glycoprotein encoded by a single gene, is structurally unrelated to the TGF- $\beta$ superfamily, but is linked functionally through its role as a high-affinity binding protein for activin [105]. Activin, a dimeric glycoprotein belonging to the TGF- $\beta$ superfamily, induces FSH and insulin secretion, ovarian follicular maturation and inhibits LH-stimulated ovarian androgen production [105]. As an activin-binding protein, follistatin can reverse each of these activin-induced responses in vitro and in vivo [105-108]. Actually, overexpression of follistatin in transgenic mice resulted in suppression of serum levels of FSH and arrested ovarian folliculogenesis [106]. Excessive activin neutralization due to increased follistatin may, therefore, reduce FSH concentrations, arrest follicular maturation, increase androgen production, and impair insulin release. Because all of these changes are typical features of PCOS [109], follistatin gene has been explored as a candidate gene in PCOS. 
Initially, Urbanek et al. examined a total of 37 potential candidate genes in 150 families with PCOS, as mentioned above, and reported statistically significant linkage only between the follistatin gene and PCOS [35]. However, subsequent more comprehensive follistatin gene studies conducted by the same authors have not obtained any significant linkage [110]. In order to detect variation in the follistatin gene, they made sequence analysis of this gene in 85 women of 19 families of PCOS patients and identified sequence variants at 17 sites. Nevertheless, only one polymorphism of these sites was common, and in addition, the site of this polymorphism was not translated [110]. They also reported similar expression of the follistatin gene mRNA in cultured fibroblasts from PCOS and control women [110]. Likewise, two studies including patients with PCOS from Singapore [111] and Spain [112] could not find any significant mutations in coding regions of the follistatin gene.

\subsection{Genes involved in insulin action and secretion}

Almost two decades ago, it was demonstrated that most women with PCOS either obese or nonobese, compared with normal women, exhibited variable degrees of insulin resistance and compensatory hyperinsulinemia [113]. Subsequently convincing evidence has been started to accumulate, and at present, it is well known that hyperinsulinemia and insulin resistance are common features of PCOS patients [64] (Figure 1). Therefore, numerous genes involved in insulin action and secretion have been explored as candidate genes in PCOS pathogenesis. The insulin gene (INS), the insulin receptor gene (INSR), the insulin receptor substrate genes (IRSs) and calpain-10 gene (CAPN10), the most relevant genes involved in insulin action and secretion, are discussed below with their controversial results.

\subsubsection{The insulin gene}

The INS is located between the genes for tyrosine hydroxylase and for IGF-II at 11p15.5, and includes variable tandem repeats (VNTR) embedded at the 5 ' regulatory region of INS [114]. The VNTR polymorphism regulates the transcriptional rate of the INS [115] and probably that of the gene encoding IGF-II [116]. The number of the repeats of the INS VNTR ranges from 26 to 200, and due to this feature INS VNTR polymorphism has three size classes. Class-I alleles compose the shorter polymorphic region, consisting of an average length of 40 repeats. Class-II alleles have an average length of 80 repeat units and are uncommon in Caucasian. Class-III alleles compose the longest polymorphic region having an average of 157 repeats [117]. Transcriptional activity of the longer polymorphic region is greater than that of the shorter one [115]. Besides their effect on regulating INS expression, they have been implicated in the pathogenesis of type-2 diabetes mellitus in many studies $[118,119]$.

It is not known whether the hyperinsulinemia detected in PCOS is an outcome of primary insulin resistance or the direct effect of pancreatic $\beta$-cell disorder, whereas defects in both insulin action $[113,120]$ and in pancreatic $\beta$-cell function $[121,122]$ have been reported. Therefore, in order to clarify the genetic basis of PCOS and to determine its association with defects in insulin secretion and action, firstly, Waterworth et al. evaluated the linkage and association of the INS VNTR polymorphisms in families with affected members with PCOS or male-pattern baldness [123]. They have found an association between PCOS and allelic variation at the INS VNTR locus in three separate populations [123]. Furthermore, they found that class III alleles, especially the III/III genotypes, were associated with anovulatory PCOS in two independent populations and were more frequent among women with polycystic ovaries with symptoms than those without symptoms [123]. In addition, in the same study, it was shown that the geometric mean of fasting serum insulin concentrations was significantly higher in families with evidence of linkage than in families with no evidence of linkage [123]. These data support the idea that the VNTR polymorphisms have a functional role on the establishment of hyperinsulinemia and/or insulin resistance component phenotypes in PCOS. The same group also reported that class III alleles were transmitted significantly more common from fathers than from mothers to affected daughter, suggesting a "parent of origin" effect in the transmission of alleles [123]. The latter finding was confirmed by Eaves et al. [124]. In support of this evidence, Michelmore et al. demonstrated that class III alleles, III/III genotype, and paternal class III allele transmissions were significantly related to increased number of PCOS features and to reduced insulin sensitivity among women with PCOS [125].

In a more comprehensive study, however, Urbanek et al. could not find any evidence for the linkage of INS and PCOS and for the association of the class III allele and of hyperandrogenemia [35]. But the difference of this study from other previous studies where the ultrasonographic findings were more commonly used was that the NIHCD selection criteria were used. Likewise, Calvo et al. studied the INS VNTR polymorphisms in Spanish women with hyperandrogenemia and failed to show any association compared to the controls [126]. Similarly, Vanková et al. studied the association of INS VNTR polymorphisms with PCOS in Czech women and failed to find any association relevant to VNTR and PCOS [127]. Using different selection criteria, studying patients with variable ethnic and geographical backgrounds, selection bias, and most importantly working with small to, at best, modest sample sizes might explain the presence of these conflicting results. Consistently, studying associations with a small sample size is known to be a major risk factor for the generation of results that cannot be replicated on consecutive examinations [128]. As a solution to this problem, more recently, Powell et al. rebutted the relationship between the INS VNTR and PCOS, using several complementary analytical approaches, including case-control, family-based, and quantitative trait association methods in more than 3500 subjects from United Kingdom and Finland [129]. 


\subsubsection{INSR}

The insulin receptor is a heterotetrameric glycoprotein composed of two $\alpha$ and two $\beta$-subunits and is encoded by the INSR located at the chromosome 19 [130]. Several studies were conducted to identify whether the mutations of INSR could explain insulin resistance in women with PCOS. Initially, direct sequencing of INSR from two obese women with PCOS did not reveal any mutations [131]. Consequently, Conway et al. [132] analyzed the sequence of the tyrosine kinase domain of INSR in 22 hyperinsulinemic patients with PCOS and Talbot et al. [133] investigated the mutations by molecular scanning of the entire coding region of INS in 24 hyperinsulinemic women with PCOS, and none of these groups detected any significant mutations related to insulin resistance in PCOS [133]. In addition, Urbanek et al., using the dinucleotide repeat marker, D19S884, found evidence for the association of the INSR with PCOS in their TDT analysis, but after correction for multiple testing, this finding lost its statistical significance [35]. However, using the same marker, Tucci et al. proved the association with INSR in women with PCOS [134]. Nevertheless, this association could not be confirmed in a consecutive study from the Mediterranean area [135]. More recently, a comprehensive study published by Urbanek et al. demonstrated a linkage with PCOS in a group of well-characterized 367 families including individuals predominantly of European origin with PCOS [136]. A broad region of the chromosome 19p13.2 was investigated and the strongest evidence for association was found with D19S884, supporting the previous findings by these authors [136].

In another study, Siegel et al. examined an SNP at the tyrosine kinase domain of INSR and found an association in lean patients with PCOS. This SNP could be a susceptibility variant for PCOS, or it can be a result of linkage disequilibrium with another INSR polymorphism, but the association is pending confirmation [137].

\subsubsection{Insulin receptor substrate proteins}

Activation of the insulin receptor following insulin binding requires the autophosphorylation of the $\beta$-subunit of the insulin receptor [138]. The consequent tyrosine kinase activity generated after autophosphorylation phosphorylates insulin receptor substrates (IRS), such as IRS-1 and IRS-2 [64]. Afterwards, IRS-1 and IRS-2 bind and activate downstream effectors, such as phosphoinositide 3-kinase, to promote the metabolic and mitogenic actions of insulin. When IRS- 1 is dysfunctional, IRS-2 is the main messenger for the intracellular transmission of the insulin signal, but it requires a higher insulin concentration for activation [139].

Several polymorphisms of IRS1 and IRS2 genes (IRS1 and IRS2) have been implicated in insulin resistance. The Gly972Arg polymorphism for IRS-1 and Gly1057Asp for IRS-2 have been shown to increase susceptibility to type-2 diabetes mellitus $[140,141]$. Although initially no evidence for linkage or association with PCOS was found with IRS1 in a family-based study conducted by Urbanek et al. [35], the potential roles of these SNPs of IRS genes in insulin resis- tance have further been investigated in PCOS. Sir-Petermann et al. reported a higher frequency of the Arg972 IRS-1 allele in PCOS patients in Chilean population [142]. Contrary to this report, El Mkadem et al. could not find any differences in the distribution of IRS-1 Gly972Arg and IRS2 Gly1057Asp alleles in PCOS patients and controls; however, they demonstrated that the Gly972Arg IRS-1 was more prevalent in insulin-resistant patients compared with the noninsulin resistant patients or control subjects [143]. Besides, they showed gene-dosage effects on fasting insulin levels for Gly972Arg IRS-1 and on 2-h plasma glucose levels during oral glucose tolerance test (OGTT) for Gly1057Asp IRS-2 in women with PCOS, while no novel mutations have been found in these genes by direct sequencing [143]. Ehrmann et al. investigated the influences of Gly972Arg IRS-1 and of Gly1057Asp IRS-2 polymorphisms in nondiabetic women with PCOS [144]. Although the IRS-1 genotype was not found to be associated with any clinical or hormonal measures in nondiabetic PCOS subjects, carrying IRS$2 \mathrm{Gly} / \mathrm{Gly}$ genotype was associated with significantly higher glucose levels in 2-h OGTT compared with carrying Gly/Asp and Asp/Asp genotypes [144]. In this study, the association of Gly/Asp genotype with lower glucose levels during 2-h OGTT [144] was just contrary to the report of El Mkadem et al. [143]. Confirming the report of El Mkadem et al. [143], Villuendas et al. showed that these polymorphisms had an equal distribution pattern among PCOS patients and controls from Spain [145]. These investigators also found that carrying the Arg972 allele for IRS-1 and carrying the homozygous Gly1057 for IRS-2 present negative effects on glucose homeostasis compared with carrying the homozygous Gly972 alleles for IRS-1 and one or two Asp1057 alleles for IRS-2, respectively [145].

In a recent study, Dilek et al. reported a higher frequency of the Gly972Arg polymorphism for IRS-1 in Turkish women with PCOS [146] in accordance with the data of Sir-Petermann et al. [142]. Moreover, similar to the data obtained by El Mkadem et al. [143] and Villuendas et al. [145], they found that the Gly972Arg carriers were more obese, more insulin-resistant and had higher fasting insulin levels when compared with the other PCOS patients and controls [146]. These investigators also studied the same Turkish PCOS patients for the potential differential effects of metformin therapy on the basis of IRS-1 genotype [147]. In this study, metformin lowered the LH, DHEAS, total testosterone, and fasting insulin levels and decreased insulin resistance and free testosterone index in Gly972Arg-negative PCOS women more effectively and significantly when compared with the Gly972Arg-positive women [147]. These findings could be taken as an indirect indicator of the relationship between the IRS-1 genotype and the insulin resistance phenotype of PCOS. Interestingly, some of the proposed mechanisms for the action of metformin at cellular level are that it might augment the tyrosine phosphorylation of the insulin receptor $\beta$-subunit and IRS proteins and also increase the insulin-dependent and nondependent cellular glucose uptake through the family of glucose transporter proteins [148]. In accordance with these proposals, Ertunc et al. 
hypothesized that variant IRS-1 proteins might not be able to transmit signals and thus might not be able to increase the glucose uptake into the muscle and adipose cells [147]. This hypothesis may, at least in part, be an explanation of the association of IRS-1 genotype with insulin resistance in some of PCOS patients; however these data are yet to be confirmed.

Overall, the association studies of IRSs with PCOS and insulin resistance phenotype of this syndrome exhibit many conflicting properties as seen with the other candidate genes for PCOS. We should emphasize however that these IRS polymorphisms seem to be associated separately with insulin resistance rather than PCOS in these studies. Therefore, more comprehensive studies are required to solve the puzzle of relations among these genes and PCOS.

\subsubsection{Calpain 10 gene}

Calpain-10 is a cysteine protease that plays a role in insulin secretion and action [149], and genetic studies have shown that variation in the gene (CAPN10) encoding calpain-10 is associated with type-2 diabetes [150]. Due to the fact that PCOS and type-2 diabetes share a number of etiologic factors $[64,151]$, Ehrmann et al. sought to determine whether variation in the CAPN10 is associated with quantitative traits related to the pathogenesis of PCOS and type2 diabetes [152]. They found an association between the $112 / 121$ haplotype of this gene and higher insulin levels in African-American women and an increased risk of PCOS in both African-American and white women [152]. Gonzales et al. investigated whether four SNPs (SNP-19, SNP43, SNP-44, and SNP-63) of the CAPN10 were associated with PCOS $[153,154]$. In support of the latter, they reported in their consecutive studies that SNP-44 of the gene is associated with PCOS in Spanish women [153, 154]. Nevertheless, using the same four SNPs, Haddad et al. could not confirm any association with PCOS in a more comprehensive study [155]. Likewise, Escobar-Morreale et al. studied three SNPs (SNP-43, SNP-44, and SNP-45) of CAPN10 and reported no association between any of those and PCOS [156]. These conflicting results suggest that definitive conclusions could only be drawn by studying larger populations probably including thousands rather than hundreds of subjects.

\subsection{Genes involved in energy homeostasis and the relevance of peroxisome proliferator-activated receptor- $\gamma$ gene}

\subsubsection{The genes of leptin, leptin receptor, and adiponectin}

Although the adipose tissue has long been regarded as an inert and passive type of connective tissue that stores and releases energy, during the last decade it has been recognized that the adipose tissue is not only a connective tissue but is also one of the active endocrine organs which secretes a wide variety of products called as adipocytokines [157]. Due to the fact that a substantial proportion of women with PCOS are overweight, many are obese and some are extremely obese, the genes of the most popular adipocytokines such as leptin and adiponectin have been investigated as candidate genes in the pathogenesis of PCOS.

Oksanen et al. sequenced the leptin gene in a small group of PCOS patients, but failed to detect any mutations of the coding exons [158]. In this study, the investigators also sequenced the leptin receptor gene and found previously identified amino acid variants in exons 2, 4, and 12 as well as the pentanucleotide insertion in the $3^{\prime}$ untranslated region [158]. However, the allele frequencies of these polymorphisms did not differ from those in the general population [158].

After the sequence polymorphisms of adiponectin gene identified in humans, most studies have focused on two polymorphisms, T45G in exon 2 and G276T in intron 2. It was demonstrated consistently that these polymorphisms associate with obesity, insulin resistance, and the risk of type2 diabetes [159-162]. In a study assessing the association of PCOS with 15 genomic variants previously described to influence insulin resistance, obesity, and/or type-2 diabetes mellitus, San Millán et al. failed to find any association between PCOS and these two common polymorphisms of the adiponectin gene [163]. Concurrently, Panidis et al. investigated the possible association of the T45G adiponectin gene polymorphisms with PCOS [164]. Although the frequency of GG, TT, and TG genotypes were similar between women with PCOS and controls, when the frequencies of GG and TG genotypes assessed together, a significant difference was observed between the groups [164]. This study reported no significant relation between the $\mathrm{T} 45 \mathrm{G}$ adiponectin gene polymorphism and circulating adiponectin levels, obesity, and the metabolic features of PCOS; however, it was observed that the carriers of the $G$ allele had a tendency for lower serum adiponectin levels in PCOS group [164]. More recently, two different studies from Greece [165] and Spain [166] rebutted the probability that the T45G and G276T polymorphisms of adiponectin gene could be associated with PCOS. Additionally, these studies reported the conflicting results about effects of these SNPs on adiponectin and hormonal variables $[165,166]$.

Taken together these data suggest that, different from the other insulin resistant disorders; the adiponectin gene seems not to play a causative role in the pathogenesis of PCOS. However, the polymorphisms of the adiponectin gene may, at least in part, have a role in the phenotypic variability of PCOS.

\subsubsection{PPAR- $\gamma$ gene}

PPAR- $\gamma$ is a transcription factor involved in adipogenesis, energy metabolism and a functional receptor for thiazolidinediones (TZDs) introduced as insulin-sensitizing agents [167]. Additionally, PPAR- $\gamma$ gene $(P P A R-\gamma)$ located on $3 \mathrm{p} 25$ [168] is a candidate gene for the regulation of adipose tissue metabolism in humans and also a susceptibility gene for the development of both obesity and diabetes [169-171]. PPAR$\gamma$ agonists, namely TZDs, currently offer an effective treatment option for the management of patients with type-2 
diabetes. Since PCOS and type-2 diabetes share certain phenotypic features such as obesity and insulin resistance, several studies investigated the potential therapeutic effects of TZDs on the ovulatory dysfunction, hirsutism, hyperandrogenism and insulin-resistance of PCOS. The vast majority of these clinical trials reported positive results [172-174].

Studies of rare mutations and frequent polymorphisms of PPAR- $\gamma$ have facilitated to improve our knowledge on the biological roles of PPAR- $\gamma$ and its implication in diseases. There are two PPAR- $\gamma$ gene polymorphisms that have been thoroughly investigated in various populations (reviewed in [175]). The first is the silent CAC478-CAT substitution which resides in the exon 6 and the second is a proline to alanine missense variant at the codon 12 of the exon 2. Studies assessing the potential impact of PPAR- $\gamma$ gene on PCOS are discussed below and summarized in Table 3.

In the first study, Urbanek et al. found no evidence for any linkage or association with PCOS for a marker close to the PPAR- $\gamma$ gene [35]. In another study, Hara et al. showed that Caucasian PCOS patients with Pro/Ala alleles are more insulin sensitive than those with Pro/Pro [176]. Recently, Hahn et al. also reported that the Pro12Ala polymorphism of $P P A R-\gamma$ are associated with increased insulin sensitivity as well as lower hirsutism scores in PCOS women [177]. Afterwards, in accordance with these data, Tok et al. reported that carriers of this polymorphism were less insulinresistant than the Pro12Ala-negative controls and patients with PCOS. The difference between the groups for carrying the polymorphism did not reach significance, probably due to very small sample size [178]. In addition, Korhonen et al. from Finland investigated the Pro12Ala polymorphism in patients with PCOS and demonstrated that the frequency of the variant Ala isoform was reduced with a slight significance in the PCOS group [179]. Furthermore, Yilmaz et al. examined the impact of the Pro12Ala polymorphism on insulin resistance in the first-degree relatives of subjects with PCOS. They found that the frequency of the variant Ala isoform was significantly reduced in the first-degree relatives of PCOS subjects compared to the controls and also demonstrated that the first-degree relatives of PCOS subjects with the Pro12Ala polymorphism were less insulin resistant than the first-degree relatives of PCOS subjects with the Pro12Pro polymorphism [180]. The latter group, in a more recent study, examined the relationship between the Pro12Ala polymorphism and the clinical and hormonal characteristics in women with PCOS. When PCOS subjects with the Pro allele and the Ala allele of PPAR- $\gamma$ were compared, they found that having the Ala allele of this nuclear receptor gene was related with reduced androgen levels, a lower Ferriman-Gallwey score, a lower insulin resistance index, a lower body mass index, and a lower waist-to-hip ratio [181]. However, this type of polymorphism was not found to be associated with PCOS in women from Spain [163], Italy [182] and China [183]. Additionally, in two different studies, Orio et al. have investigated the impact of $P P A R-\gamma$ gene polymorphisms in PCOS pathogenesis. First, they studied the exon-6 C142T allele of PPAR- $\gamma$ and showed a higher frequency in Italian women with PCOS compared to the controls [182]. Subse- quently, they investigated the putative influence of PPAR- $\gamma$ gene Pro12Ala polymorphism on the adiponectin levels in PCOS patients and in healthy women. However, they failed to demonstrate any effect of Pro12Ala polymorphism on adiponectin levels in neither group [184].

The limited size of the study populations and the low stringency in diagnostic criteria are the limitations of the genetic association studies seeking for the relevance of the PPARg gene with PCOS and thus, should be interpreted cautiously. Likewise, the lack of a clear-cut association to the polymorphisms does not rule out the implications of PPARg on the pathogenesis of PCOS. Even though genetic association studies do not clearly establish any link between PCOS and $P P A R-\gamma$ polymorphisms, functional investigations still point out the suspicious role of $P P A R-\gamma$ on PCOS. SetoYoung et al. demontrated that PPAR- $\gamma$ ligands stimulate the steroidogenesis on human ovarian steroidogenic tissue [191]. Pioglitazone treatment increased growth hormone secretion and stimulated levels in PCOS patients in a randomized trial [192]. Authors comment that this action might be a function of improved insulin sensitivity [192]. While these functional studies implicate the relevance of $P P A R-\gamma$ function to PCOS, the molecular mechanisms to explain the beneficial action of PPAR- $\gamma$ activators on the clinical picture of PCOS are still obscure. This effect may be a consequence of potentiating the insulin sensitivity on the periphery and the gonads [192]. Jansen et al. employed a more mechanistic approach and compared the gene expression profiles in PCOS ovaries to control subjects and female to male transsexuals [193]. These authors draw special attention on the differentiation promoting effect and interplay between the histon deacetylase (HDAC) function and the PPAR- $\gamma$ gene [193]. Interestingly the antiepileptic drug valproic acid has both HDAC inhibitory activity and PPAR- $\gamma$ agonist action that create a condition that resembles the PCOS picture during administration [194]. As a consequence, further functional studies are required to elucidate the transcriptional cascade and the events that link PPAR- $\gamma$ function to PCOS pathogenesis.

\subsection{Genes involved in chronic inflammation}

Chronic inflammation appears to play a role in the development of insulin resistance (Figure 1) and cardiovascular disease [195] and it might be involved in the pathogenesis of PCOS [196] although not all agree [189]. Some genomic variants related to inflammation have been studied in PCOS.

\subsubsection{TNF- $\alpha$}

Tumor necrosis factor (TNF)- $\alpha$ is cytokine secreted by adipose tissue that plays an important role in insulin resistance [197]. The variants that are studied up to date are -308 G/A [185, 186, 198], -1196 C/T, -1125 G/C, -1031 T/C, -863 C/A, -857 C/T, -316 G/A, -238 G/A, - 163 G/A [198], and $-850 \mathrm{C} / \mathrm{T}$ [187]. The polymorphisms in the TNF$\alpha$ gene do not seem to have a key role in the pathogenesis of PCOS. In a study by Escobar-Morreole et al., the carriers of -308 A alleles showed increased serum androgen and 
TABLe 2: Summary of the studies of candidate genes in PCOS.

\begin{tabular}{|c|c|c|c|c|}
\hline Gene & Locus/variant & Subjects/phenotypic trait & ${ }^{(a)}$ Assoc. & References \\
\hline \multicolumn{5}{|c|}{ Genes involved in ovarian and adrenal steroidogenesis } \\
\hline \multirow{7}{*}{ CYP11a } & \multirow{3}{*}{$(\mathrm{tttta})_{n}$} & $\begin{array}{l}\text { PCOS/ } \\
\text { hyperandrogenemia }\end{array}$ & Yes & Gharani et al. [29] \\
\hline & & $\begin{array}{l}\text { PCOS/ } \\
\text { body mass index }\end{array}$ & Yes & Wang et al. [31] \\
\hline & & $\begin{array}{l}\text { PCOS/ } \\
\text { hyperandrogenemia }\end{array}$ & Yes & Diamanti-Kandarakis et al. [30] \\
\hline & $\begin{array}{l}\text { D15S519 } \\
\text { D15S520 }\end{array}$ & $\begin{array}{l}\text { PCOS/ } \\
\text { hyperandrogenemia }\end{array}$ & No & Urbanek et al. [35] \\
\hline & $(\mathrm{tttta})_{n}$ & $\begin{array}{l}\text { Hirsutism/ } \\
\text { hyperandrogenism }\end{array}$ & No & San Millán et al. [36] \\
\hline & $(\mathrm{tttta})_{n}$ & $\begin{array}{l}\text { PCOS/ } \\
\text { hyperandrogenemia }\end{array}$ & No & Tan et al. $[33,34]$ \\
\hline & $\begin{array}{l}\text { D15S520,1500 bp to } \\
\text { D15S520 }\end{array}$ & $\begin{array}{l}\mathrm{PCOS},{ }^{(b)} \mathrm{PCO} / \\
\text { testosterone levels }\end{array}$ & No & Gaasenbeek et al. [32] \\
\hline \multirow{5}{*}{ CYP21 } & \multirow{5}{*}{$\begin{array}{l}\text { Heterozygosity for } \\
\text { CYP2 } 1 \text { mutations }\end{array}$} & $\begin{array}{l}\text { Premature pubarche/ } \\
\text { hyperandrogenism }\end{array}$ & Yes & Witchel et al. [39] \\
\hline & & Hyperandrogenism & Yes & Witchel et al. [40] \\
\hline & & $\begin{array}{l}\text { Hirsutism/ } \\
\text { origin of androgen excess }\end{array}$ & No & Escobar-Morreale et al. [41] \\
\hline & & $\begin{array}{l}\text { Hirsutism, PCOS/ } \\
\text { adrenal hyperresponsiveness }\end{array}$ & No & Glintborg et al. [42] \\
\hline & & $\begin{array}{l}\text { PCOS/ } \\
\text { hyperandrogenemia }\end{array}$ & No & Witchel et al. [43] \\
\hline \multirow{8}{*}{ CYP17 } & \multirow{5}{*}{$-34 \mathrm{~T} / \mathrm{C}^{(c)} \mathrm{SNP}$} & PCOS & Yes & Carey et al. [52] \\
\hline & & $\begin{array}{l}\text { PCOS/ } \\
\text { hyperandrogenemia }\end{array}$ & Yes & Diamanti-Kandarakis et al. [53] \\
\hline & & $\begin{array}{l}\text { PCOS/ } \\
\text { hyperandrogenemia }\end{array}$ & No & Gharani et al. [54] \\
\hline & & $\begin{array}{l}\text { PCOS/ } \\
\text { hyperandrogenemia }\end{array}$ & No & Techatraisak et al. [55] \\
\hline & & $\begin{array}{l}\text { PCOS/ } \\
\text { hormone profile }\end{array}$ & No & Marszalek et al. [57] \\
\hline & $\begin{array}{l}\text { Mutation scanning/ } \\
\text { no mutation }\end{array}$ & $\begin{array}{l}\text { Mild } \\
\text { hyperandrogenism }\end{array}$ & No & Witchel et al. [56] \\
\hline & D10S192 & PCOS & No & Urbanek et al. [35] \\
\hline & $\begin{array}{l}\text { T/C substitution in } \\
\text { the } 5^{\prime}(d) \mathrm{PR}\end{array}$ & $\begin{array}{l}\text { PCOS/ } \\
{ }^{(e)} \text { DHEAS levels }\end{array}$ & No & Kahsar-Miller et al. [58] \\
\hline \multirow[b]{3}{*}{ CYP19 } & CYP19 & PCOS & No & Urbanek et al. [35] \\
\hline & $(\mathrm{tttta})_{n} / \mathrm{D} 15 \mathrm{~S} 103$ & PCOS & No & Gharani et al. [29] \\
\hline & $\begin{array}{l}\text { Aromatase SNP_50 } \\
\text { genotype Aromatase } \\
\text { distal promoter } \\
\text { region variation }\end{array}$ & $\begin{array}{l}\text { PCOS symptom score } \\
\text { testosterone } \\
\text { concentrations }\end{array}$ & Yes & Petry et al. $[74,75]$ \\
\hline
\end{tabular}


Table 2: Continued.

\begin{tabular}{|c|c|c|c|c|}
\hline Gene & Locus/variant & Subjects/phenotypic trait & Assoc. & References \\
\hline \multicolumn{5}{|c|}{ Genes involved in steroid hormone effects } \\
\hline $\mathrm{AR}$ & $\mathrm{AR}$ & PCOS & No & Urbanek et al. [35] \\
\hline \multirow{6}{*}{ SHBG gene } & \multirow{3}{*}{$\mathrm{AR}(\mathrm{CAG})_{n}$} & $\begin{array}{l}\text { PCOS/infertile and } \\
\text { fertile women }\end{array}$ & No & Mifsud et al. [83] \\
\hline & & PCOS/infertility & Yes & Hickey et al. [84] \\
\hline & & $\begin{array}{l}\mathrm{PCOS} /(f) \\
\text { testosterone levels }\end{array}$ & No & Jääskeläinen et al. [85] \\
\hline & $(\text { TAAAA })_{n}$ & PCOS/SHBG levels & Yes & Xita et al. [90] \\
\hline & Asp327Asn & Hirsutism/SHBG levels & Yes & Cousin et al. [91] \\
\hline & $\mathrm{D} 17 \mathrm{~S} 1353$ & PCOS & No & Urbanek et al. [35] \\
\hline \multicolumn{5}{|c|}{ Genes involved in gonadotropin action and regulation } \\
\hline \multirow{6}{*}{$L H \beta$} & \multirow{3}{*}{ Trp8Arg; Ilg15Thr } & $\begin{array}{l}\text { PCOS/higher frequency of } \\
\text { the SNPs in obese PCOS }\end{array}$ & Yes & Rajkhowa et al. [98] \\
\hline & & $\begin{array}{l}\text { PCOS/lower frequency of } \\
\text { the SNPs in obese PCOS }\end{array}$ & Yes & Tapanainen et al. [99] \\
\hline & & Menstrual disorders & No & Ramanujam et al. [100] \\
\hline & Ser102 Gly & Menstrual disorders & Yes & Ramanujam et al. [100] \\
\hline & Trp8Arg; Ilg15Thr & PCOS & No & Elter et al. [101] \\
\hline & Several SNPs & $\begin{array}{l}\text { Ovulatory disorders } \\
\text { including PCOS }\end{array}$ & Yes & Takahashi et al. [103] \\
\hline \multirow{4}{*}{ Follistatin gene } & $\begin{array}{l}\text { D5S474 } \\
\text { D5S623 } \\
\text { D5S822 }\end{array}$ & PCOS & Yes & Urbanek et al. [35] \\
\hline & $\begin{array}{l}\text { Mutation scanning/ } \\
\text { variants at } 17 \text { sites }\end{array}$ & PCOS & No & Urbanek et al. [110] \\
\hline & $\begin{array}{l}\text { Mutation scanning/ } \\
\text { no mutation }\end{array}$ & PCOS & No & Liao et al. [111] \\
\hline & $\begin{array}{l}\text { Mutation scanning/ } \\
\text { no mutation except } \\
\text { G951A ( silent mutation) }\end{array}$ & PCOS/hormone profile & No & Calvo et al. [112] \\
\hline \multicolumn{5}{|c|}{ Genes involved in insulin action and secretion } \\
\hline \multirow{7}{*}{ INS } & \multirow{7}{*}{ INS VNRT } & $\begin{array}{l}\text { PCOS/premature male } \\
\text { pattern baldness }\end{array}$ & Yes & Waterworth et al. [123] \\
\hline & & PCOS & Yes & Eaves et al. [124] \\
\hline & & $\begin{array}{l}\text { PCOS/insulin resistance } \\
\text { and hyperandrogenemia }\end{array}$ & Yes & Michelmore et al. [125] \\
\hline & & $\begin{array}{l}\text { PCOS/ } \\
\text { hyperandrogenemia }\end{array}$ & No & Urbanek et al. [35] \\
\hline & & Hyperandrogenemia & No & Calvo et al. [126] \\
\hline & & $\begin{array}{l}\text { PCOS/insulin } \\
\text { secretion and action }\end{array}$ & No & Vankova et al. [127] \\
\hline & & $\begin{array}{l}\text { PCOS; PCO; } \\
\text { testosterone level }\end{array}$ & No & Powell et al. [129] \\
\hline
\end{tabular}


Table 2: Continued.

\begin{tabular}{|c|c|c|c|c|}
\hline Gene & Locus/variant & Subjects/phenotypic trait & Assoc. & References \\
\hline \multirow{6}{*}{ INSR } & Mutation scanning & PCOS/insulin resistance & No & Talbot et al. [133] \\
\hline & \multirow{4}{*}{ D19S884 } & PCOS & Border & Urbanek et al. [35] \\
\hline & & PCOS & Yes & Tucci et al. [134] \\
\hline & & PCOS & No & Villuendas et al. [135] \\
\hline & & PCOS & Yes & Urbanek et al. [136] \\
\hline & $\mathrm{C} 10923 \mathrm{~T}$ & PCOS/lean subjects & Yes & Siegal et al. [137] \\
\hline \multirow{3}{*}{ IRS } & $I R S 1$ & PCOS & No & Urbanek et al. [35] \\
\hline & Gly972Arg (IRS1) & PCOS & Yes & Sir-Petermann et al. [142] \\
\hline & $\begin{array}{l}\text { Gly972Arg (IRS1) } \\
\text { Gly1057Asp(IRS2) }\end{array}$ & PCOS/insulin resistance & Yes & El-Mkadem et al. [143] \\
\hline \multirow{4}{*}{ IRS } & Gly972Arg (IRS1) & $\begin{array}{l}\text { PCOS/insulin and } \\
\text { glucose levels }\end{array}$ & No & Ehrmann et al. [144] \\
\hline & $\begin{array}{l}\text { Gly972Arg (IRS1) } \\
\text { Gly1057Asp(IRS2) }\end{array}$ & $\begin{array}{l}\text { PCOS/glucose } \\
\text { homeostasis }\end{array}$ & No & Villuendas et al. [145] \\
\hline & \multirow[b]{2}{*}{ Gly972Arg (IRS1) } & $\begin{array}{l}\text { PCOS/insulin resistance, } \\
\text { and obesity }\end{array}$ & Yes & Dilek et al. [146] \\
\hline & & $\begin{array}{l}\text { PCOS/insulin resistance, } \\
\text { hormone profile, and } \\
\text { metformin effects }\end{array}$ & Yes & Ertunc et al. [147] \\
\hline \multirow{6}{*}{ CAPN10 } & UCSNP-19, -43 , and -63 & PCOS/insulin levels & Yes & Ehrmann et al. [152] \\
\hline & UCSNP-19, -43, -44, & PCOS & Yes & Gonzales et al. $[153,154]$ \\
\hline & and -63 & PCOS/insulin levels & No & Haddad et al. [155] \\
\hline & UCSNP-43 & Hirsutism/hirsutism score & Yes & Escobar-Morreale et al. [156] \\
\hline & UCSNP-44 & $\begin{array}{l}\text { Hirsutism/PCOS, } \\
\text { idiopathic hirsutism, and } \\
\text { hyperandrogenism }\end{array}$ & No & Escobar-Morreale et al. [156] \\
\hline & UCSNP-45 & $\begin{array}{l}\text { Hirsutism/idiopathic } \\
\text { hirsutism }\end{array}$ & Yes & Escobar-Morreale et al. [156] \\
\hline \multicolumn{5}{|c|}{ Genes involved in energy homeostasis } \\
\hline $\begin{array}{l}\text { Leptin gene \& } \\
\text { Leptin receptor }\end{array}$ & $\begin{array}{l}\text { Mutation scanning of } \\
\text { the leptin gene; } \\
\text { polymorphism in } \\
\text { leptin receptor gene }\end{array}$ & PCOS/obesity & No & Oksanen et al. [158] \\
\hline \multirow{4}{*}{ Adiponectin gene } & $\begin{array}{l}\text { T45G in exon } 2 \\
\text { G276T in intron } 2\end{array}$ & PCOS & No & San Millán et al. [163] \\
\hline & $\mathrm{T} 45 \mathrm{G}$ in exon 2 & PCOS & No & Panidis et al. [164] \\
\hline & T45G in exon 2 & PCOS & No & Xita et al. [165] \\
\hline & G276T in intron 2 & PCOS & No & Escobar-Morreale et al. [166] \\
\hline \multicolumn{5}{|c|}{ Genes involved in chronic inflammation } \\
\hline \multirow{3}{*}{$T N F-\alpha$} & \multirow{3}{*}{$-308 \mathrm{G} / \mathrm{A}$} & PCOS & No & Milner et al. [185] \\
\hline & & PCOS & No & Mao et al. [186] \\
\hline & & PCOS & No & Korhonen et al. [187] \\
\hline
\end{tabular}


TABle 2: Continued.

\begin{tabular}{l|l|lll}
\hline Gene & Locus/variant & Subjects/phenotypic trait & Assoc. & References \\
\hline TNFR2 gene & Met196Arg & $\begin{array}{l}\text { PCOS/ } \\
\text { hyperandrogenism }\end{array}$ & Yes & Peral et al. [188] \\
\hline IL-6 & -174 G/C & PCOS & Yes & Mohlig et al. [189] \\
\hline $\begin{array}{l}\text { IL-6 signal } \\
\text { transducer gp 130 }\end{array}$ & Gly148Arg & $\begin{array}{l}\text { PCOS/ } \\
\text { hyperandrogenism }\end{array}$ & Yes & Escobar-Morreale et al. [190] \\
\hline IL-6 receptor- $\alpha$ & CA repeats & $\begin{array}{l}\text { PCOS/obesity, and } \\
\text { Hyperandrogenism }\end{array}$ & Yes & Escobar-Morreale et al. [190]
\end{tabular}

(a) Assoc.: association.

(b) PCO: polycystic ovaries.

(c) SNP: single nucleotide polymorphism.

(d) PR: promoter region.

${ }^{(e)}$ DHEAS: dehydroepiandrosterone sulfate.

${ }^{(f)}$ BMI: body mass index.

TABLE 3: Genes involved in energy homeostasis: PPAR- $\gamma$.

\begin{tabular}{|c|c|c|c|c|}
\hline Gene & Locus/variant & Subjects/phenotypic trait & (a) Assoc. & References \\
\hline \multirow{9}{*}{$\begin{array}{l}\text { PPAR- } \gamma \\
\text { Gene }\end{array}$} & D3S1263 & PCOS & No & Urbanek et al. [35] \\
\hline & \multirow{6}{*}{ Pro12Ala } & PCOS/reduced insulin resistance & Yes & Hara et al. [176] \\
\hline & & $\begin{array}{l}\text { PCOS/lower hirsutism scores, } \\
\text { increased insulin sensitivity }\end{array}$ & Yes & Hahn et al. [177] \\
\hline & & Reduced insulin resistance & (b) Yes & Tok et al. [178] \\
\hline & & PCOS & Yes & Korhoren et al. [179] \\
\hline & & PCOS & No & San Millán et al. [163] \\
\hline & & PCOS & No & Orio et al. [182] \\
\hline & & $\begin{array}{l}\text { PCOS/clinical and hormonal } \\
\text { characteristics }\end{array}$ & Yes & Yilmaz et al. [181] \\
\hline & CAC478CAT & PCOS/obesity, leptin levels & Yes & Orio et al. [182] \\
\hline $\begin{array}{l}P P A R-\gamma \& \\
P G C-1 \alpha\end{array}$ & $\begin{array}{l}\text { Pro12Ala \& } \\
\text { Gly482Ser }\end{array}$ & PCOS & No & Wang et al. [183] \\
\hline
\end{tabular}

${ }^{(a)}$ Assoc.: association. ${ }^{(b)}$ No statistical significance.

17-hydroxyprogesterone levels before and after stimulation with the GnRH analogue leuprolide [198]. These findings may indicate that TNF- $\alpha$ gene polymorphism might be a modifying factor for phenotypic traits.

Other genes involved in chronic inflammation, such as TNFR2 (type-2 TNF receptor) gene [188], IL-6 [189, 199], IL-6 signal transducer gp 130 [190], IL-6 receptor [190] genes have also been investigated as a candidate gene for pathogenesis of PCOS. The results of these candidate gene studies and those discussed above are summarized in Table 2.

\subsection{Other genes}

\subsubsection{Plasminogen activator inhibitor-1 gene}

Patients with PCOS cluster cardiovascular risk factors [6]. Abnormalities in the coagulation and fibrinolytic pathways contribute to the development of CVD in PCOS [200].
Elevated plasminogen activator inhibitor-1 (PAI-1) levels are associated with increased cardiovascular risk and increased thrombogenic tendency, and in general, women with PCOS also have an increased activity of PAI-1 [6]. The 4G/5G polymorphism in the promoter region of the PAI-1 is associated with increased plasma PAI-1 concentrations in patients with type-2 diabetes and myocardial infarction [201]. In order to understand the role of the PAI-1 polymorphism in PCOS patients, Diamanti-Kandarakis et al. investigated this polymorphism in Greek women with PCOS and found a higher frequency of the $4 \mathrm{G} / 4 \mathrm{G}$ and $4 \mathrm{G} / 5 \mathrm{G}$ genotypic subtypes in PCOS compared with controls [202]. These investigators also reported that PCOS women have higher levels of PAI-1 and that the presence of the $4 \mathrm{G}$ allele in the PAI- 1 promoter region of the gene further increases the PAI-1 levels [202].

In addition to the genes mentioned above in detail, many different genes such as HSD3B2 [35, 203], 17 $\alpha$-hydroxysteroid dehydrogenases $[35,204]$, dopamine receptor $[205,206]$, IGF 
TABle 4: Major limitations of genetic studies in PCOS.

\begin{tabular}{ll}
\hline $\begin{array}{l}\text { Lack of universally accepted diagnostic } \\
\text { criteria and definition }\end{array}$ & $\begin{array}{l}\text { - NICHD criteria } \\
\text { - Rltrasonographic criteria }\end{array}$ \\
\hline & $\begin{array}{l}\text { - Premature baldness } \\
\text { - Increased pilosity }\end{array}$ \\
Male phenotype? & - Increased DHEAS levels? \\
& - Insulin resistance, glucose intolerance \\
\hline Relatively small sample size of the & - Potential statistical error \\
study populations & - Difficulty in studying more than one generation \\
\hline Affected reproduction & - Bias? \\
\hline Nonrandom ascertainment of families & - Autosomal Dominant [8, 12] \\
\hline Obscurity in the mode of inheritance & - Monogenic [14, 17] \\
\hline Variable penetrance and expressivity & - Difficulty in assignment of the phenotype \\
\hline Locus heterogeneity & (affected versus unaffected) \\
\hline Environmental interactions & $\bullet$ Summarized in Section 4. \\
\hline
\end{tabular}

[35, 163], aldosterone synthetase [207], paraoxonase [163], glycogen synthetase [208], resistin [209], apoprotein E [210] have been studied up to date in a variety of PCOS populations. Similar to the studies described in detail above, either negative or controversial results have been obtained.

\section{LIMITATIONS AND CHALLENGES FOR GENETIC STUDIES IN PCOS}

PCOS is a common and complex disorder. Similar to other complex traits such as type-2 diabetes and obesity, the complexity of the underlying genetic model as well as potential gene-gene and gene-environment interactions pose a difficulty for genetic analyses. Major limitations and challenges in the genetic studies of PCOS are shown in Table 4.

\subsection{Issues related to phenotype and genotype}

There are several major limitations relevant to the phenotype and genotype studies of PCOS. Firstly, there has been an ongoing debate for the definition of and the diagnostic criteria for PCOS, and different diagnostic criteria used in different studies introduce complexity into the comparison of the results [211]. Secondly, how to assign affected status of men in PCOS families remains obscure although several clinical and biochemical characteristics have been suggested for the male phenotype including premature baldness, increased pilosity, increased DHEAS levels, exaggerated responses to $\mathrm{GnRH}$ or ACTH, and insulin resistance and glucose intolerance [109]. Thirdly, relatively small sample sizes of the study populations might result in statistical errors in population-based genetic studies of association for unrelated cases and controls [212].

Linkage studies run on large families spanning at least three generations including more than one affected and unaffected individuals are successful for the identification of a susceptibility locus. As infertility is one of the primary manifestations of PCOS, this is the most important fact which limits the availability of large pedigrees. In addition, nonrandom assignment of families increases the potential for selection bias. We should also note that since the mode of inheritance expressivity and penetrance is obscure, it is difficult to assess if one individual is affected or unaffected. Moreover, comparison of one pedigree to another may also harbor obstacles due that PCOS appears to be a highly heterogeneous disorder, with locus and allelic heterogeneity both between and within families likely.

\subsection{Environmental factors and compensatory adaptation}

The impact of environmental factors for the development of PCOS is currently an active area of research. One important point is that the compensatory adaptations achieved in the intrauterine life might be associated with PCOS later in life (reviewed by Escobar-Morreale [213]). There is a recent evidence from animal studies that metabolic compensatory adaptations of carbohydrate metabolism and insulin signaling acquired in the intrauterine life is carried on to the postnatal life [214]. This intrauterine compensatory adaptation might as well be implicated by epigenetic factors such as DNA methylation. 


\section{CONCLUSIONS AND FUTURE PERSPECTIVES}

Based on familial, metabolic, and endocrine data, PCOS can be taken as a complex genetic trait similar to type-2 diabetes and obesity. It appears that there are multiple inherited, environmental or acquired factors that may increase the risk for developing PCOS. The efforts to identify the genes and mutations predisposing to PCOS up to date have been primarily based on association and linkage studies with functional candidate genes only a few of which exhibited significant evidence of association with PCOS. Furthermore, most of the positive findings obtained with PCOS phenotypes have not been replicated in more than one population. These results are not surprising considering that genes with such a great impact on the phenotype are not expected to be responsible for PCOS. However, it is important to emphasize that relatively small sample size of study populations is a major limitation for most of the studies.

Identification of the candidate genes and understanding of their function holds the promise for the establishment of the specific molecular basis for PCOS. More studies with larger sample sizes on different populations are needed to determine whether suggested functional candidate genes play any role at all in the etiology of PCOS. Two recent advances in genetics, namely genome-wide scan approach and the HapMap project, will serve as tools for both identification of novel loci and narrowing the known genomic regions for PCOS. The acquisition of genetic information regarding PCOS will be most useful for providing new insights into the pathophysiology of the syndrome and will eventually have a profound effect on the clinical management of the PCOS patients.

\section{ACKNOWLEDGMENT}

This work was supported, in part, by the Turkish Academy of Sciences (Grant TUBA-GEBIP-2006 to BOY).

\section{REFERENCES}

[1] R. Azziz, K. S. Woods, R. Reyna, T. J. Key, E. S. Knochenhauer, and B. O. Yildiz, "The prevalence and features of the polycystic ovary syndrome in an unselected population," Journal of Clinical Endocrinology and Metabolism, vol. 89, no. 6, pp. 2745-2749, 2004.

[2] J. K. Zawadzki and A. Dunaif, "Diagnostic criteria for polycystic ovary syndrome," in Polycystic Ovary Syndrome, A. Dunaif, J. Givens, F. Haseltine, and G. R. Merriam, Eds., pp. 377-384, Blackwell Scientific, Boston, Mass, USA, 1992.

[3] The Rotterdam ESHRE/ASRM-Sponsored PCOS Consensus Workshop Group, "Revised 2003 consensus on diagnostic criteria and long-term health risks related to polycystic ovary syndrome," Fertility and Sterility, vol. 81, no. 1, pp. 19-25, 2004.

[4] The Rotterdam ESHRE/ASRM-Sponsored PCOS Consensus Workshop Group, "Revised 2003 consensus on diagnostic criteria and long-term health risks related to polycystic ovary syndrome," Human Reproduction, vol. 19, no. 1, pp. 41-47, 2004
[5] F. Ovalle and R. Azziz, "Insulin resistance, polycystic ovary syndrome, and type 2 diabetes mellitus," Fertility and Sterility, vol. 77, no. 6, pp. 1095-1105, 2002.

[6] R. S. Legro, "Polycystic ovary syndrome and cardiovascular disease: a premature association?" Endocrine Reviews, vol. 24, no. 3, pp. 302-312, 2003.

[7] P. Hardiman, O. S. Pillay, and W. Atiomo, "Polycystic ovary syndrome and endometrial carcinoma," Lancet, vol. 361, no. 9371, pp. 1810-1812, 2003.

[8] H. E. Cooper, W. N. Spellacy, K. A. Prem, and W. D. Cohen, "Hereditary factors in the Stein-Leventhal syndrome," American Journal of Obstetrics and Gynecology, vol. 100, no. 3, pp. 371-387, 1968.

[9] R. S. Wilroy Jr., J. R. Givens, W. L. Wiser, S. A. Coleman, R. N. Andersen, and R. L. Summitt, "Hyperthecosis: an inheritable form of polycystic ovarian disease," Birth Defects: Original Article Series, vol. 11, no. 4, pp. 81-85, 1975.

[10] J. R. Givens, "Familial polycystic ovarian disease," Endocrinology and Metabolism Clinics of North America, vol. 17, no. 4, pp. 771-783, 1988.

[11] D. Ferriman and A. W. Purdie, "The inheritance of polycystic ovarian disease and a possible relationship to premature balding," Clinical Endocrinology, vol. 11, no. 3, pp. 291-300, 1979.

[12] O. Lunde, P. Magnus, L. Sandvik, and S. Hoglo, "Familial clustering in the polycystic ovarian syndrome," Gynecologic and Obstetric Investigation, vol. 28, no. 1, pp. 23-30, 1989.

[13] W. M. Hague, J. Adams, S. T. Reeders, T. E. A. Peto, and H. S. Jacobs, "Familial polycystic ovaries: a genetic disease?" Clinical Endocrinology, vol. 29, no. 6, pp. 593-605, 1988.

[14] A. H. Carey, K. L. Chan, F. Short, D. White, R. Williamson, and S. Franks, "Evidence for a single gene effect causing polycystic ovaries and male pattern baldness," Clinical Endocrinology, vol. 38, no. 6, pp. 653-658, 1993.

[15] R. J. Norman, S. Masters, and W. Hague, "Hyperinsulinemia is common in family members of women with polycystic ovary syndrome," Fertility and Sterility, vol. 66, no. 6, pp. 942-947, 1996.

[16] S. Colilla, N. J. Cox, and D. A. Ehrmann, "Heritability of insulin secretion and insulin action in women with polycystic ovary syndrome and their first degree relatives," Journal of Clinical Endocrinology and Metabolism, vol. 86, no. 5, pp. 2027-2031, 2001.

[17] R. S. Legro, D. Driscoll, J. F. Strauss III, J. Fox, and A. Dunaif, "Evidence for a genetic basis for hyperandrogenemia in polycystic ovary syndrome," Proceedings of the National Academy of Sciences of the United States of America, vol. 95, no. 25, pp. 14956-14960, 1998.

[18] R. S. Legro, R. Bentley-Lewis, D. Driscoll, S. C. Wang, and A. Dunaif, "Insulin resistance in the sisters of women with polycystic ovary syndrome: association with hyperandrogenemia rather than menstrual irregularity," Journal of Clinical Endocrinology and Metabolism, vol. 87, no. 5, pp. 2128-2133, 2002.

[19] R. S. Legro, A. R. Kunselman, L. Demers, S. C. Wang, R. Bentley-Lewis, and A. Dunaif, "Elevated dehydroepiandrosterone sulfate levels as the reproductive phenotype in the brothers of women with polycystic ovary syndrome," Journal of Clinical Endocrinology and Metabolism, vol. 87, no. 5, pp. 2134-2138, 2002.

[20] M. D. Kahsar-Miller, C. Nixon, L. R. Boots, R. C. Go, and R. Azziz, "Prevalence of polycystic ovary syndrome (PCOS) 
in first-degree relatives of patients with PCOS," Fertility and Sterility, vol. 75, no. 1, pp. 53-58, 2001.

[21] B. O. Yildiz, H. Yarali, H. Oguz, and M. Bayraktar, "Glucose intolerance, insulin resistance, and hyperandrogenemia in first degree relatives of women with polycystic ovary syndrome," Journal of Clinical Endocrinology and Metabolism, vol. 88, no. 5, pp. 2031-2036, 2003.

[22] S. Franks, N. Gharani, D. Waterworth, et al., "The genetic basis of polycystic ovary syndrome," Human Reproduction, vol. 12, no. 12, pp. 2641-2648, 1997.

[23] S. Jahanfar and J. A. Eden, "Genetic and non-genetic theories on the etiology of polycystic ovary syndrome," Gynecological Endocrinology, vol. 10, no. 5, pp. 357-364, 1996.

[24] A. Govind, M. S. Obhrai, and R. N. Clayton, "Polycystic ovaries are inherited as an autosomal dominant trait: analysis of 29 polycystic ovary syndrome and 10 control families," Journal of Clinical Endocrinology and Metabolism, vol. 84, no. 1, pp. 38-43, 1999.

[25] R. E. March, "Gene mapping by linkage and association analysis," Applied Biochemistry and Biotechnology - Part B Molecular Biotechnology, vol. 13, no. 2, pp. 113-122, 1999.

[26] L. J. Palmer and L. R. Cardon, "Shaking the tree: mapping complex disease genes with linkage disequilibrium," Lancet, vol. 366, no. 9492, pp. 1223-1234, 2005.

[27] G. McVean, C. C. Spencer, and R. Chaix, "Perspectives on human genetic variation from the HapMap Project," PLoS Genetics, vol. 1, no. 4, p. e54, 2005.

[28] S. Franks, C. Gilling-Smith, N. Gharani, and M. McCarthy, "Pathogenesis of polycystic ovary syndrome: evidence for a genetically determined disorder of ovarian androgen production," Human Fertility, vol. 3, no. 2, pp. 77-79, 2000.

[29] N. Gharani, D. M. Waterworth, S. Batty, et al., "Association of the steroid synthesis gene CYP11a with polycystic ovary syndrome and hyperandrogenism," Human Molecular Genetics, vol. 6, no. 3, pp. 397-402, 1997.

[30] E. Diamanti-Kandarakis, M. I. Bartzis, A. T. Bergiele, T. C. Tsianateli, and C. R. Kouli, "Microsatellite polymorphism $(t t t a)_{n}$ at -528 base pairs of gene CYP $11 \alpha$ influences hyperandrogenemia in patients with polycystic ovary syndrome," Fertility and Sterility, vol. 73, no. 4, pp. 735-741, 2000.

[31] Y. Wang, X.-K. Wu, Y.-X. Cao, et al., "Microsatellite polymorphism of $(t t t t a)_{n}$ in the promoter of CYP1la gene in Chinese women with polycystic ovary syndrome," Zhonghua Yi Xue Za Zhi, vol. 85, no. 48, pp. 3396-3400, 2005.

[32] M. Gaasenbeek, B. L. Powell, U. Sovio, et al., "Large-scale analysis of the relationship between CYP11A promoter variation, polycystic ovarian syndrome, and serum testosterone," Journal of Clinical Endocrinology and Metabolism, vol. 89, no. 5, pp. 2408-2413, 2004.

[33] L. Tan and G. Zhu, "Relationship between the microsatellite polymorphism of CYP $11 \alpha$ gene and the pathogenesis of hyperandrogenism of polycystic ovary syndrome in Chinese," Chinese Journal of Medical Genetics, vol. 22, no. 2, pp. 216218, 2005.

[34] L. Tan and G. Zhu, "Role of the pentanucleotide $(t t t t a)_{n}$ polymorphisms of Cyp11alpha gene in the pathogenesis of hyperandrogenism in Chinese women with polycystic ovary syndrome," Journal of Huazhong University of Science and Technology. Medical Sciences, vol. 25, no. 2, pp. 212-214, 2005.

[35] M. Urbanek, R. S. Legro, D. A. Driscoll, et al., "Thirty-seven candidate genes for polycystic ovary syndrome: strongest evidence for linkage is with follistatin," Proceedings of the National Academy of Sciences of the United States of America, vol. 96, no. 15, pp. 8573-8578, 1999.

[36] J. L. San Millán, J. Sancho, R. M. Calvo, and H. F. EscobarMorreale, "Role of the pentanucleotide $(t t t a)_{n}$ polymorphism in the promoter of the CYP11a gene in the pathogenesis of hirsutism," Fertility and Sterility, vol. 75, no. 4, pp. 797802, 2001.

[37] H. Escobar-Morreale, F. Pazos, N. Potau, R. Garcia-Robles, J. M. Sancho, and C. Varela, "Ovarian suppression with triptorelin and adrenal stimulation with adrenocorticotropin in functional hyperadrogenism: role of adrenal and ovarian cytochrome P450c17 $\alpha$," Fertility and Sterility, vol. 62, no. 3, pp. 521-530, 1994.

[38] R. Azziz, E. L. Bradley Jr., H. D. Potter, and L. R. Boots, "Adrenal androgen excess in women: lack of a role for 17hydroxylase and 17,20-lyase dysregulation," Journal of Clinical Endocrinology and Metabolism, vol. 80, no. 2, pp. 400-405, 1995.

[39] S. F. Witchel and C. E. Aston, "The role of heterozygosity for CYP21 in the polycystic ovary syndrome," Journal of Pediatric Endocrinology and Metabolism, vol. 13, supplement 5, pp. 1315-1317, 2000.

[40] S. F. Witchel, P. A. Lee, M. Suda-Hartman, and E. P. Hoffman, "Hyperandrogenism and manifesting heterozygotes for 21hydroxylase deficiency," Biochemical and Molecular Medicine, vol. 62, no. 2, pp. 151-158, 1997.

[41] H. F. Escobar-Morreale, J. L. San Millán, R. R. Smith, J. Sancho, and S. F. Witchel, "The presence of the 21-hydroxylase deficiency carrier status in hirsute women: phenotypegenotype correlations," Fertility and Sterility, vol. 72, no. 4, pp. 629-638, 1999.

[42] D. Glintborg, A. P. Hermann, K. Brusgaard, J. Hangaard, C. Hagen, and M. Andersen, "Significantly higher adrenocorticotropin-stimulated cortisol and 17-hydroxyprogesterone levels in 337 consecutive, premenopausal, caucasian, hirsute patients compared with healthy controls," Journal of Clinical Endocrinology and Metabolism, vol. 90, no. 3, pp. 1347-1353, 2005.

[43] S. F. Witchel, M. Kahsar-Miller, C. E. Aston, C. White, and R. Azziz, "Prevalence of CYP21 mutations and IRS1 variant among women with polycystic ovary syndrome and adrenal androgen excess," Fertility and Sterility, vol. 83, no. 2, pp. 371-375, 2005.

[44] J. Picado-Leonard and W. L. Miller, "Cloning and sequence of the human gene for P450c17 (steroid 17 $\alpha$-hydroxylase/17,20 lyase): similarity with the gene for P450c21," DNA, vol. 6, no. 5, pp. 439-448, 1987.

[45] L. Sharp, A. H. Cardy, S. C. Cotton, and J. Little, "CYP17 gene polymorphisms: prevalence and associations with hormone levels and related factors. A HuGE review," American Journal of Epidemiology, vol. 160, no. 8, pp. 729-740, 2004.

[46] R. L. Rosenfield, R. B. Barnes, J. F. Cara, and A. W. Lucky, "Dysregulation of cytochrome P450c $17 \alpha$ as the cause of polycystic ovarian syndrome," Fertility and Sterility, vol. 53, no. 5, pp. 785-791, 1990.

[47] R. L. Rosenfield, R. B. Barnes, and D. A. Ehrmann, "Studies of the nature of 17-hydroxyprogesterone hyperresponsiveness to gonadotropin-releasing hormone agonist challenge in functional ovarian hyperandrogenism," Journal of Clinical Endocrinology and Metabolism, vol. 79, no. 6, pp. 1686-1692, 1994. 
[48] H. F. Escobar-Morreale, J. Serrano-Gotarredona, R. GarcíaRobles, J. M. Sancho, and C. Varela, "Lack of an ovarian function influence on the increased adrenal androgen secretion present in women with functional ovarian hyperandrogenism," Fertility and Sterility, vol. 67, no. 4, pp. 654-662, 1997.

[49] J. K. Wickenheisser, P. G. Quinn, V. L. Nelson, R. S. Legro, J. F. Strauss III, and J. M. McAllister, "Differential activity of the cytochrome P450 17 $\alpha$-hydroxylase and steroidogenic acute regulatory protein gene promoters in normal and polycystic ovary syndrome theca cells," Journal of Clinical Endocrinology and Metabolism, vol. 85, no. 6, pp. 2304-2311, 2000.

[50] J. K. Wickenheisser, V. L. Nelson-Degrave, P. G. Quinn, and J. M. McAllister, "Increased cytochrorne P450 17 $\alpha$-hydroxylase promoter function in theca cells isolated from patients with polycystic ovary syndrome involves nuclear factor-1," Molecular Endocrinology, vol. 18, no. 3, pp. 588-605, 2004.

[51] J. K. Wickenheisser, V. L. Nelson-DeGrave, and J. M. McAllister, "Dysregulation of cytochrome P450 17 $\alpha$-hydroxylase messenger ribonucleic acid stability in theca cells isolated from women with polycystic ovary syndrome," Journal of Clinical Endocrinology and Metabolism, vol. 90, no. 3, pp. 1720-1727, 2005.

[52] A. H. Carey, D. Waterworth, K. Patel, et al., "Polycystic ovaries and premature male pattern baldness are associated with one allele of the steroid metabolism gene CYP17," $\mathrm{Hu}$ man Molecular Genetics, vol. 3, no. 10, pp. 1873-1876, 1994.

[53] E. Diamanti-Kandarakis, M. I. Bartzis, E. D. Zapanti, et al., "Polymorphism T $\rightarrow$ C (-34 bp) of gene CYP17 promoter in Greek patients with polycystic ovary syndrome," Fertility and Sterility, vol. 71, no. 3, pp. 431-435, 1999.

[54] N. Gharani, D. M. Waterworth, R. Williamson, and S. Franks, " 5 ' polymorphism of the CYP17 gene is not associated with serum testosterone levels in women with polycystic ovaries," Journal of Clinical Endocrinology and Metabolism, vol. 81, no. 11, p. 4174, 1996.

[55] K. Techatraisak, G. S. Conway, and G. Rumsby, "Frequency of a polymorphism in the regulatory region of the $17 \alpha$ hydroxylase-17,20-lyase (CYP17) gene in hyperandrogenic states," Clinical Endocrinology, vol. 46, no. 2, pp. 131-134, 1997.

[56] S. F. Witchel, P. A. Lee, M. Suda-Hartman, R. Smith, and E. P. Hoffman, " $17 \alpha$-hydroxylase/17,20-lyase dysregulation is not caused by mutations in the coding regions of CYP17," Journal of Pediatric and Adolescent Gynecology, vol. 11, no. 3, pp. 133137, 1998.

[57] B. Marszalek, M. Laciński, N. Babych, et al., "Investigations on the genetic polymorphism in the region of CYP17 gene encoding $5^{\prime}$-UTR in patients with polycystic ovarian syndrome," Gynecological Endocrinology, vol. 15, no. 2, pp. 123128, 2001.

[58] M. Kahsar-Miller, L. R. Boots, A. Bartolucci, and R. Azziz, "Role of a CYP17 polymorphism in the regulation of circulating dehydroepiandrosterone sulfate levels in women with polycystic ovary syndrome," Fertility and Sterility, vol. 82, no. 4, pp. 973-975, 2004.

[59] L.-H. Zhang, H. Rodriguez, S. Ohno, and W. L. Miller, "Serine phosphorylation of human P450c17 increases 17,20-lyase activity: implications for adrenarche and the polycystic ovary syndrome," Proceedings of the National Academy of Sciences of the United States of America, vol. 92, no. 23, pp. 10619-10623, 1995.
[60] K.-N. Qin and R. L. Rosenfield, "Role of cytochrome P450c17 in polycystic ovary syndrome," Molecular and Cellular Endocrinology, vol. 145, no. 1-2, pp. 111-121, 1998.

[61] S. Takayama, M. F. White, and C. R. Kahn, "Phorbol esterinduced serine phosphorylation of the insulin receptor decreases its tyrosine kinase activity," Journal of Biological Chemistry, vol. 263, no. 7, pp. 3440-3447, 1988.

[62] J. E. Chin, M. Dickens, J. M. Tavare, and R. A. Roth, “Overexpression of protein kinase $\mathrm{C}$ isoenzymes $\alpha, \beta \mathrm{I}, \gamma$, and $\epsilon$ in cells overexpressing the insulin receptor. Effects on receptor phosphorylation and signaling," Journal of Biological Chemistry, vol. 268, no. 9, pp. 6338-6347, 1993.

[63] A. Dunaif, J. Xia, C.-B. Book, E. Schenker, and Z. Tang, "Excessive insulin receptor serine phosphorylation in cultured fibroblasts and in skeletal muscle. A potential mechanism for insulin resistance in the polycystic ovary syndrome," Journal of Clinical Investigation, vol. 96, no. 2, pp. 801-810, 1995.

[64] A. Dunaif, "Insulin resistance and the polycystic ovary syndrome: mechanism and implications for pathogenesis," Endocrine Reviews, vol. 18, no. 6, pp. 774-800, 1997.

[65] E. R. Simpson, M. S. Mahendroo, G. D. Means, et al., "Aromatase cytochrome P450, the enzyme responsible for estrogen biosynthesis," Endocrine Reviews, vol. 15, no. 3, pp. 342355, 1994.

[66] D. W. Nebert, M. Adesnik, M. J. Coon, et al., "The P450 gene superfamily: recommended nomenclature," DNA, vol. 6, no. 1, pp. 1-11, 1987.

[67] S. Chen, M. J. Besman, R. S. Sparkes, et al., "Human aromatase: cDNA cloning, Southern blot analysis, and assignment of the gene to chromosome 15," DNA, vol. 7, no. 1, pp. 27-38, 1988.

[68] N. Harada, H. Ogawa, M. Shozu, and K. Yamada, "Genetic studies to characterize the origin of the mutation in placental aromatase deficiency," American Journal of Human Genetics, vol. 51, no. 3, pp. 666-672, 1992.

[69] Y. Ito, C. R. Fisher, F. A. Conte, M. M. Grumbach, and E. R. Simpson, "Molecular basis of aromatase deficiency in an adult female with sexual infantilism and polycystic ovaries," Proceedings of the National Academy of Sciences of the United States of America, vol. 90, no. 24, pp. 11673-11677, 1993.

[70] K. Takayama, T. Fukaya, H. Sasano, et al., "Immunohistochemical study of steroidogenesis and cell proliferation in polycystic ovarian syndrome," Human Reproduction, vol. 11, no. 7, pp. 1387-1392, 1996.

[71] G. F. Erickson, A. J. W. Hsueh, M. E. Quigley, R. W. Rebar, and S. S. Yen, "Functional studies of aromatase activity in human granulosa cells from normal and polycystic ovaries," Journal of Clinical Endocrinology and Metabolism, vol. 49, no. 4, pp. 514-519, 1979.

[72] A. J. Jakimiuk, S. R. Weitsman, P. R. Brzechffa, and D. A. Magoffin, "Aromatase mRNA expression in individual follicles from polycystic ovaries," Molecular Human Reproduction, vol. 4, no. 1, pp. 1-8, 1998.

[73] D. Söderlund, P. Canto, S. Carranza-Lira, and J. P. Méndez, "No evidence of mutations in the P450 aromatase gene in patients with polycystic ovary syndrome," Human Reproduction, vol. 20, no. 4, pp. 965-969, 2005.

[74] C. J. Petry, K. K. Ong, K. F. Michelmore, et al., "Association of aromatase (CYP 19) gene variation with features of hyperandrogenism in two populations of young women," Human Reproduction, vol. 20, no. 7, pp. 1837-1843, 2005. 
[75] C. J. Petry, K. K. Ong, K. F. Michelmore, et al., "Associations between common variation in the aromatase gene promoter region and testosterone concentrations in two young female populations," Journal of Steroid Biochemistry and Molecular Biology, vol. 98, no. 4-5, pp. 199-206, 2006.

[76] D. B. Lubahn, D. R. Joseph, P. M. Sullivan, H. F. Willard, F. S. French, and E. M. Wilson, "Cloning of human androgen receptor complementary DNA and localization to the X chromomose," Science, vol. 240, no. 4850, pp. 327-330, 1988.

[77] M. A. Carson-Jurica, W. T. Schrader, and B. W. O’Malley, "Steroid receptor family: structure and functions," Endocrine Reviews, vol. 11, no. 2, pp. 201-220, 1990.

[78] N. L. Chamberlain, E. D. Driver, and R. L. Miesfeld, "The length and location of CAG trinucleotide repeats in the androgen receptor $\mathrm{N}$-terminal domain affect transactivation function," Nucleic Acids Research, vol. 22, no. 15, pp. 31813186, 1994.

[79] E. Giovannucci, M. J. Stampfer, K. Krithivas, et al., "The CAG repeat within the androgen receptor gene and its relationship to prostate cancer," Proceedings of the National Academy of Sciences of the United States of America, vol. 94, no. 7, pp. 3320-3323, 1997.

[80] T. G. Tut, F. J. Ghadessy, M. A. Trifiro, L. Pinsky, and E. L. Yong, "Long polyglutamine tracts in the androgen receptor are associated with reduced trans-activation, impaired sperm production, and male infertility," Journal of Clinical Endocrinology and Metabolism, vol. 82, no. 11, pp. 37773782, 1997.

[81] A. T. Dowsing, E. L. Yong, M. Clark, R. I. McLachlan, D. M. De Kretser, and A. O. Trounson, "Linkage between male infertility and trinucleotide repeat expansion in the androgenreceptor gene," Lancet, vol. 354, no. 9179, pp. 640-643, 1999.

[82] T. R. Rebbeck, P. W. Kantoff, K. Krithivas, et al., "Modification of BRCA1-associated breast cancer risk by the polymorphic androgen-receptor CAG repeat," American Journal of Human Genetics, vol. 64, no. 5, pp. 1371-1377, 1999.

[83] A. Mifsud, S. Ramirez, and E. L. Yong, "Androgen receptor gene CAG trinucleotide repeats in anovulatory infertility and polycystic ovaries," Journal of Clinical Endocrinology and Metabolism, vol. 85, no. 9, pp. 3484-3488, 2000.

[84] T. Hickey, A. Chandy, and R. J. Norman, "The androgen receptor CAG repeat polymorphism and X-chromosome inactivation in Australian Caucasian women with infertility related to polycystic ovary syndrome," Journal of Clinical Endocrinology and Metabolism, vol. 87, no. 1, pp. 161-165, 2002.

[85] J. Jääskeläinen, S. Korhonen, R. Voutilainen, M. Hippeläinen, and S. Heinonen, "Androgen receptor gene CAG length polymorphism in women with polycystic ovary syndrome," Fertility and Sterility, vol. 83, no. 6, pp. 1724-1728, 2005.

[86] M. Pugeat, J. C. Crave, J. Tourniaire, and M. G. Forest, "Clinical utility of sex hormone-binding globulin measurement," Hormone Research, vol. 45, no. 3-5, pp. 148-155, 1996.

[87] C. Selby, "Sex hormone binding globulin: origin, function and clinical significance," Annals of Clinical Biochemistry, vol. 27, part 6, pp. 532-541, 1990.

[88] D. Berube, G. E. Seralini, R. Gagne, and G. L. Hammond, "Localization of the human sex hormone-binding globulin gene (SHBG) to the short arm of chromosome $17(17 \mathrm{p} 12 \rightarrow$ p13)," Cytogenetics and Cell Genetics, vol. 54, no. 1-2, pp. 6567, 1990.

[89] K. N. Hogeveen, M. Talikka, and G. L. Hammond, "Human sex hormone-binding globulin promoter activity is influenced by a (TAAAA $)_{n}$ repeat element within an Alu sequence," Journal of Biological Chemistry, vol. 276, no. 39, pp. 36383-36390, 2001.

[90] N. Xita, A. Tsatsoulis, A. Chatzikyriakidou, and I. Georgiou, "Association of the (TAAAA) ${ }_{n}$ repeat polymorphism in the sex hormone-binding globulin (SHBG) gene with polycystic ovary syndrome and relation to SHBG serum levels," Journal of Clinical Endocrinology and Metabolism, vol. 88, no. 12, pp. 5976-5980, 2003.

[91] P. Cousin, L. Calemard-Michel, H. Lejeune, et al., "Influence of SHBG gene pentanucleotide TAAAA repeat and D327N polymorphism on serum sex hormone-binding globulin concentration in hirsute women," Journal of Clinical Endocrinology and Metabolism, vol. 89, no. 2, pp. 917-924, 2004.

[92] A. H. Balen, "Hypersecretion of luteinizing hormone and the polycystic ovary syndrome," Human Reproduction, vol. 8, supplement 2, pp. 123-128, 1993.

[93] J. E. Hall, A. E. Taylor, K. A. Martin, and W. F. Crowley, "New approaches to the study of the neuroendocrine abnormalities of women with the polycystic ovarian syndrome," Annals of the New York Academy of Sciences, vol. 687, pp. 182-192, 1993.

[94] K. Furui, N. Suganuma, S.-I. Tsukahara, et al., "Identification of two point mutations in the gene coding luteinizing hormone (LH) $\beta$-subunit, associated with immunologically anomalous LH variants," Journal of Clinical Endocrinology and Metabolism, vol. 78, no. 1, pp. 107-113, 1994.

[95] C. Nilsson, K. Pettersson, R. P. Millar, K. A. Coerver, M. M. Matzuk, and I. T. Huhtaniemi, "Worldwide frequency of a common genetic variant of luteinizing hormone: an international collaborative research," Fertility and Sterility, vol. 67, no. 6, pp. 998-1004, 1997.

[96] K. Okuda, T. Yamada, H. Imoto, H. Komatsubara, and O. Sugimoto, "Antigenic alteration of an anomalous human luteinizing hormone caused by two chorionic gonadotropintype amino-acid substitutions," Biochemical and Biophysical Research Communications, vol. 200, no. 1, pp. 584-590, 1994.

[97] A.-M. Haavisto, K. Pettersson, M. Bergendahl, A. Virkamaki, and I. Huhtaniemi, "Occurrence and biological properties of a common genetic variant of luteinizing hormone," Journal of Clinical Endocrinology and Metabolism, vol. 80, no. 4, pp. 1257-1263, 1995.

[98] M. Rajkhowa, J. A. Talbot, P. W. Jones, et al., "Prevalence of an immunological LH $\beta$-subunit variant in a UK population of healthy women and women with polycystic ovary syndrome," Clinical Endocrinology, vol. 43, no. 3, pp. 297-303, 1995.

[99] J. S. Tapanainen, R. Koivunen, B. C. J. M. Fauser, et al., "A new contributing factor to polycystic ovary syndrome: the genetic variant of luteinizing hormone," Journal of Clinical Endocrinology and Metabolism, vol. 84, no. 5, pp. 1711-1715, 1999.

[100] L. N. Ramanujam, W. X. Liao, A. C. Roy, A. Loganath, H. H. Goh, and S. C. Ng, "Association of molecular variants of luteinizing hormone with menstrual disorders," Clinical Endocrinology, vol. 51, no. 2, pp. 243-246, 1999.

[101] K. Elter, C. T. Erel, N. Cine, U. Ozbek, B. Hacihanefioglu, and E. Ertungealp, "Role of the mutations $\operatorname{Trp} 8 \rightarrow$ Arg and Ile15 $\rightarrow$ Thr of the human luteinizing hormone $\beta$-subunit in women with polycystic ovary syndrome," Fertility and Sterility, vol. 71, no. 3, pp. 425-430, 1999.

[102] A. C. Roy, W.-X. Liao, Y. Chen, S. Arulkumaran, and S. S. Ratnam, "Identification of seven novel mutations in LH 
$\beta$-subunit gene by SSCP," Molecular and Cellular Biochemistry, vol. 165, no. 2, pp. 151-153, 1996.

[103] K. Takahashi, K. Karino, H. Kanasaki, et al., "Influence of missense mutation and silent mutation of $\mathrm{LH} \beta$-subunit gene in Japanese patients with ovulatory disorders," European Journal of Human Genetics, vol. 11, no. 5, pp. 402-408, 2003.

[104] S. Franks, N. Gharani, and M. McCarthy, "Candidate genes in polycystic ovary syndrome," Human Reproduction Update, vol. 7, no. 4, pp. 405-410, 2001.

[105] P. G. Knight and C. Glister, "Potential local regulatory functions of inhibins, activins and follistatin in the ovary," Reproduction, vol. 121, no. 4, pp. 503-512, 2001.

[106] Q. Guo, T. R. Kumar, T. Woodruff, L. A. Hadsell, F. J. DeMayo, and M. M. Matzuk, "Overexpression of mouse follistatin causes reproductive defects in transgenic mice," Molecular Endocrinology, vol. 12, no. 1, pp. 96-106, 1998.

[107] J. P. Mather, A. Moore, and R.-H. Li, "Activins, inhibins, and follistatins: further thoughts on a growing family of regulators," Proceedings of the Society for Experimental Biology and Medicine, vol. 215, no. 3, pp. 209-222, 1997.

[108] H. Shibata, M. Kanzaki, T. Takeuchi, J.-I. Miyazaki, and I. Kojima, "Two distinct signaling pathways activated by activin a in glucose-responsive pancreatic $\beta$-cell lines," Journal of Molecular Endocrinology, vol. 16, no. 3, pp. 249-258, 1996.

[109] R. S. Legro, R. Spielman, M. Urbanek, D. Driscoll, J. F. Strauss III, and A. Dunaif, "Phenotype and genotype in polycystic ovary syndrome," Recent Progress in Hormone Research, vol. 53, pp. 217-256, 1998.

[110] M. Urbanek, X. Wu, K. R. Vickery, et al., "Allelic variants of the follistatin gene in polycystic ovary syndrome," Journal of Clinical Endocrinology and Metabolism, vol. 85, no. 12, pp. 4455-4461, 2000.

[111] W. X. Liao, A. C. Roy, and S. C. Ng, "Preliminary investigation of follistatin gene mutations in women with polycystic ovary syndrome," Molecular Human Reproduction, vol. 6, no. 7, pp. 587-590, 2000.

[112] R. M. Calvo, G. Villuendas, J. Sancho, J. L. San Millán, and H. F. Escobar-Morreale, "Role of the follistatin gene in women with polycystic ovary syndrome," Fertility and Sterility, vol. 75, no. 5, pp. 1020-1023, 2001.

[113] A. Dunaif, K. R. Segal, W. Futterweit, and A. Dobrjansky, "Profound peripheral insulin resistance, independent of obesity, in polycystic ovary syndrome," Diabetes, vol. 38, no. 9, pp. 1165-1174, 1989.

[114] C. Junien and V. van Heyningen, "Report of the committee on the genetic constitution of chromosome 11," Cytogenetics and Cell Genetics, vol. 55, no. 1-4, pp. 153-169, 1990.

[115] G. C. Kennedy, M. S. German, and W. J. Rutter, “The minisatellite in the diabetes susceptibility locus IDDM2 regulates insulin transcription," Nature Genetics, vol. 9, no. 3, pp. 293298, 1995.

[116] J. Paquette, N. Giannoukakis, C. Polychronakos, P. Vafiadis, and C. Deal, "The INS 5 ' variable number of tandem repeats is associated with IGF2 expression in humans," Journal of Biological Chemistry, vol. 273, no. 23, pp. 14158-14164, 1998.

[117] G. I. Bell, M. J. Selby, and W. J. Rutter, "The highly polymorphic region near the human insulin gene is composed of simple tandemly repeating sequences," Nature, vol. 295, no. 5844, pp. 31-35, 1982.

[118] J. U. Weaver, P. G. Kopelman, and G. A. Hitman, "Central obesity and hyperinsulinaemia in women are associated with polymorphism in the $5^{\prime}$ flanking region of the human insulin gene," European Journal of Clinical Investigation, vol. 22, no. 4, pp. 265-270, 1992.

[119] K. K. L. Ong, D. I. Phillips, C. Fall, et al., "The insulin gene VNTR, type 2 diabetes and birth weight," Nature Genetics, vol. 21, no. 3, pp. 262-263, 1999.

[120] A. Dunaif, K. R. Segal, D. R. Shelley, G. Green, A. Dobrjansky, and T. Licholai, "Evidence for distinctive and intrinsic defects in insulin action in polycystic ovary syndrome," Diabetes, vol. 41, no. 10, pp. 1257-1266, 1992.

[121] J. Holte, T. Bergh, C. Berne, L. Wide, and H. Lithell, "Restored insulin sensitivity but persistently increased early insulin secretion after weight loss in obese women with polycystic ovary syndrome," Journal of Clinical Endocrinology and Metabolism, vol. 80, no. 9, pp. 2586-2593, 1995.

[122] N. M. O’Meara, J. D. Blackman, D. A. Ehrmann, et al., “Defects in $\beta$-cell function in functional ovarian hyperandrogenism," Journal of Clinical Endocrinology and Metabolism, vol. 76, no. 5, pp. 1241-1247, 1993.

[123] D. M. Waterworth, S. T. Bennett, N. Gharani, et al., "Linkage and association of insulin gene VNTR regulatory polymorphism with polycystic ovary syndrome," Lancet, vol. 349, no. 9057, pp. 986-990, 1997.

[124] I. A. Eaves, S. T. Bennett, P. Forster, et al., "Transmission ratio distortion at the INS-IGF2 VNTR," Nature Genetics, vol. 22, no. 4, pp. 324-325, 1999.

[125] K. Michelmore, K. Ong, S. Mason, et al., "Clinical features in women with polycystic ovaries: relationships to insulin sensitivity, insulin gene VNTR and birth weight," Clinical Endocrinology, vol. 55, no. 4, pp. 439-446, 2001.

[126] R. M. Calvo, D. Tellería, J. Sancho, J. L. San Millán, and H. F. Escobar-Morreale, "Insulin gene variable number of tandem repeats regulatory polymorphism is not associated with hyperandrogenism in Spanish women," Fertility and Sterility, vol. 77, no. 4, pp. 666-668, 2002.

[127] M. Vanková, J. Vrbíková, M. Hill, O. Cinek, and B. Bendlová, "Association of insulin gene VNTR polymorphism with polycystic ovary syndrome," Annals of the New York Academy of Sciences, vol. 967, pp. 558-565, 2002.

[128] J. P. A. Ioannidis, T. A. Trikalinos, E. E. Ntzani, and D. G. Contopoulos-Ioannidis, "Genetic associations in large versus small studies: an empirical assessment," Lancet, vol. 361, no. 9357, pp. 567-571, 2003.

[129] B. L. Powell, L. Haddad, A. Bennett, et al., "Analysis of multiple data sets reveals no association between the insulin gene variable number tandem repeat element and polycystic ovary syndrome or related traits," Journal of Clinical Endocrinology and Metabolism, vol. 90, no. 5, pp. 2988-2993, 2005.

[130] I. D. Goldfine, "The insulin receptor: molecular biology and transmembrane signaling," Endocrine Reviews, vol. 8, no. 3, pp. 235-255, 1987.

[131] L. R. Sorbara, Z. Tang, A. Cama, et al., "Absence of insulin receptor gene mutations in three insulin-resistant women with the polycystic ovary syndrome," Metabolism, vol. 43, no. 12, pp. 1568-1574, 1994.

[132] G. S. Conway, C. Avey, and G. Rumsby, "The tyrosine kinase domain of the insulin receptor gene is normal in women with hyperinsulinaemia and polycystic ovary syndrome," Human Reproduction, vol. 9, no. 9, pp. 1681-1683, 1994.

[133] J. A. Talbot, E. J. Bicknell, M. Rajkhowa, A. Krook, S. O'Rahilly, and R. N. Clayton, "Molecular scanning of the 
insulin receptor gene in women with polycystic ovarian syndrome," Journal of Clinical Endocrinology and Metabolism, vol. 81, no. 5, pp. 1979-1983, 1996.

[134] S. Tucci, W. Futterweit, E. S. Concepcion, et al., "Evidence for association of polycystic ovary syndrome in Caucasian women with a marker at the insulin receptor gene locus," Journal of Clinical Endocrinology and Metabolism, vol. 86, no. 1, pp. 446-449, 2001.

[135] G. Villuendas, H. F. Escobar-Morreale, F. Tosi, J. Sancho, P. Moghetti, and J. L. San Millán, "Association between the D19S884 marker at the insulin receptor gene locus and polycystic ovary syndrome," Fertility and Sterility, vol. 79, no. 1, pp. 219-220, 2003.

[136] M. Urbanek, A. Woodroffe, K. G. Ewens, et al., "Candidate gene region for polycystic ovary syndrome on chromosome 19p13.2," Journal of Clinical Endocrinology and Metabolism, vol. 90, no. 12, pp. 6623-6629, 2005.

[137] S. Siegel, W. Futterweit, T. F. Davies, et al., "A C/T single nucleotide polymorphism at the tyrosine kinase domain of the insulin receptor gene is associated with polycystic ovary syndrome," Fertility and Sterility, vol. 78, no. 6, pp. 1240-1243, 2002.

[138] S. R. Hubbard, L. Wei, L. Ellis, and W. A. Hendrickson, "Crystal structure of the tyrosine kinase domain of the human insulin receptor," Nature, vol. 372, no. 6508, pp. 746-754, 1994.

[139] M. F. White, "IRS proteins and the common path to diabetes," American Journal of Physiology - Endocrinology and Metabolism, vol. 283, no. 3, pp. E413-E422, 2002.

[140] D. J. Burks and M. F. White, "IRS proteins and beta-cell function," Diabetes, vol. 50, supplement 1, pp. S140-S145, 2001.

[141] A. Jellema, M. P. A. Zeegers, E. J. M. Feskens, P. C. Dagnelie, and R. P. Mensink, "Gly972Arg variant in the insulin receptor substrate- 1 gene and association with type 2 diabetes: a metaanalysis of 27 studies," Diabetologia, vol. 46, no. 7, pp. 990 995, 2003.

[142] T. Sir-Petermann, F. Pérez-Bravo, B. Angel, M. Maliqueo, M. Calvillan, and A. Palomino, "G972R polymorphism of IRS1 in women with polycystic ovary syndrome," Diabetologia, vol. 44, no. 9, pp. 1200-1201, 2001.

[143] S. A. El Mkadem, C. Lautier, F. Macari, et al., "Role of allelic variants Gly972Arg of IRS-1 and Gly1057Asp of IRS-2 in moderate-to-severe insulin resistance of women with polycystic ovary syndrome," Diabetes, vol. 50, no. 9, pp. 21642168, 2001.

[144] D. A. Ehrmann, X. Tang, I. Yoshiuchi, N. J. Cox, and G. I. Bell, "Relationship of insulin receptor substrate-1 and -2 genotypes to phenotypic features of polycystic ovary syndrome," Journal of Clinical Endocrinology and Metabolism, vol. 87, no. 9, pp. 4297-4300, 2002.

[145] G. Villuendas, J. I. Botella-Carretero, B. Roldán, J. Sancho, H. F. Escobar-Morreale, and J. L. San Millán, "Polymorphisms in the insulin receptor substrate-1 (IRS-1) gene and the insulin receptor substrate-2 (IRS-2) gene influence glucose homeostasis and body mass index in women with polycystic ovary syndrome and non-hyperandrogenic controls," Human Reproduction, vol. 20, no. 11, pp. 3184-3191, 2005.

[146] S. Dilek, D. Ertunc, E. C. Tok, E. M. Erdal, and A. Aktas, "Association of Gly972Arg variant of insulin receptor substrate1 with metabolic features in women with polycystic ovary syndrome," Fertility and Sterility, vol. 84, no. 2, pp. 407-412, 2005.

[147] D. Ertunc, E. C. Tok, A. Aktas, E. M. Erdal, and S. Dilek, “The importance of IRS-1 Gly972Arg polymorphism in evaluating the response to metformin treatment in polycystic ovary syndrome," Human Reproduction, vol. 20, no. 5, pp. 1207-1212, 2005.

[148] N. F. Wiernsperger and C. J. Bailey, "The antihyperglycaemic effect of metformin therapeutic and cellular mechanisms," Drugs, vol. 58, supplement 1, pp. 31-39, 1999, discussion 7582.

[149] S. K. Sreenan, Y.-P. Zhou, K. Otani, et al., "Calpains play a role in insulin secretion and action," Diabetes, vol. 50, no. 9, pp. 2013-2020, 2001.

[150] Y. Horikawa, N. Oda, N. J. Cox, et al., "Genetic variation in the gene encoding calpain-10 is associated with type 2 diabetes mellitus," Nature Genetics, vol. 26, no. 2, pp. 163-175, 2000.

[151] D. A. Ehrmann, "Relation of functional ovarian hyperandrogenism to non-insulin dependent diabetes mellitus," Baillière's Clinical Obstetrics and Gynaecology, vol. 11, no. 2, pp. 335-347, 1997.

[152] D. A. Ehrmann, P. E. H. Schwarz, M. Hara, et al., "Relationship of calpain-10 genotype to phenotypic features of polycystic ovary syndrome," Journal of Clinical Endocrinology and Metabolism, vol. 87, no. 4, pp. 1669-1673, 2002.

[153] A. Gonzalez, E. Abril, A. Roca, et al., "Comment: CAPN10 alleles are associated with polycystic ovary syndrome," Journal of Clinical Endocrinology and Metabolism, vol. 87, no. 8, pp. 3971-3976, 2002.

[154] A. Gonzalez, E. Abril, A. Roca, et al., "Specific CAPN10 gene haplotypes influence the clinical profile of polycystic ovary patients," Journal of Clinical Endocrinology and Metabolism, vol. 88, no. 11, pp. 5529-5536, 2003.

[155] L. Haddad, J. C. Evans, N. Gharani, et al., "Variation within the type 2 diabetes susceptibility gene calpain-10 and polycystic ovary syndrome," Journal of Clinical Endocrinology and Metabolism, vol. 87, no. 6, pp. 2606-2610, 2002.

[156] H. F. Escobar-Morreale, B. Peral, G. Villuendas, R. M. Calvo, J. Sancho, and J. L. San Millán, "Common single nucleotide polymorphisms in intron 3 of the calpain-10 gene influence hirsutism," Fertility and Sterility, vol. 77, no. 3, pp. 581-587, 2002.

[157] E. E. Kershaw and J. S. Flier, "Adipose tissue as an endocrine organ," Journal of Clinical Endocrinology and Metabolism, vol. 89, no. 6, pp. 2548-2556, 2004.

[158] L. Oksanen, A. Tiitinen, J. Kaprio, H. A. Koistinen, S.-L. Karonen, and K. Kontula, "No evidence for mutations of the leptin or leptin receptor genes in women with polycystic ovary syndrome," Molecular Human Reproduction, vol. 6, no. 10, pp. 873-876, 2000.

[159] F. B. Hu, A. Doria, T. Li, et al., "Genetic variation at the adiponectin locus and risk of type 2 diabetes in women," $D i$ abetes, vol. 53, no. 1, pp. 209-213, 2004.

[160] K. Hara, P. Boutin, Y. Mori, et al., "Genetic variation in the gene encoding adiponectin is associated with an increased risk of type 2 diabetes in the Japanese population," Diabetes, vol. 51, no. 2, pp. 536-540, 2002.

[161] M. Stumvoll, O. Tschritter, A. Fritsche, et al., "Association of the T-G polymorphism in adiponectin (Exon 2) with obesity and insulin sensitivity: interaction with family history of type 2 diabetes," Diabetes, vol. 51, no. 1, pp. 37-41, 2002.

[162] C. Menzaghi, T. Ercolino, R. Di Paola, et al., "A haplotype at the adiponectin locus is associated with obesity and other features of the insulin resistance syndrome," Diabetes, vol. 51, no. 7, pp. 2306-2312, 2002. 
[163] J. L. San Millán, M. Cortón, G. Villuendas, J. Sancho, B. Peral, and H. F. Escobar-Morreale, "Association of the polycystic ovary syndrome with genomic variants related to insulin resistance, type 2 diabetes mellitus, and obesity," Journal of Clinical Endocrinology and Metabolism, vol. 89, no. 6, pp. 2640-2646, 2004.

[164] D. Panidis, A. Kourtis, A. Kukuvitis, et al., "Association of the T45G polymorphism in exon 2 of the adiponectin gene with polycystic ovary syndrome: role of $\Delta 4$-androstenedione," Human Reproduction, vol. 19, no. 8, pp. 1728-1733, 2004.

[165] N. Xita, I. Georgiou, A. Chatzikyriakidou, et al., "Effect of adiponectin gene polymorphisms on circulating adiponectin and insulin resistance indexes in women with polycystic ovary syndrome," Clinical Chemistry, vol. 51, no. 2, pp. 416423, 2005.

[166] H. F. Escobar-Morreale, G. Villuendas, J. I. Botella-Carretero, et al., "Adiponectin and resistin in PCOS: a clinical, biochemical and molecular genetic study," Human Reproduction, vol. 21, no. 9, pp. 2257-2265, 2006.

[167] S. M. Rangwala and M. A. Lazar, "Peroxisome proliferatoractivated receptor $\gamma$ in diabetes and metabolism," Trends in Pharmacological Sciences, vol. 25, no. 6, pp. 331-336, 2004.

[168] A. Elbrecht, Y. Chen, C. A. Cullinan, et al., "Molecular cloning, expression and characterization of human peroxisome proliferator activated receptors $\gamma 1$ and $\gamma 2$," Biochemical and Biophysical Research Communications, vol. 224, no. 2, pp. 431-437, 1996.

[169] A. J. Vidal-Puig, R. V. Considine, M. Jimenez-Liñan, et al., "Peroxisome proliferator-activated receptor gene expression in human tissues: effects of obesity, weight loss, and regulation by insulin and glucocorticoids," Journal of Clinical Investigation, vol. 99, no. 10, pp. 2416-2422, 1997.

[170] P. Tontonoz, E. Hu, R. A. Graves, A. I. Budavari, and B. M. Spiegelman, "mPPAR $\gamma 2$ : tissue-specific regulator of an adipocyte enhancer," Genes and Development, vol. 8, no. 10, pp. 1224-1234, 1994.

[171] D. Altshuler, J. N. Hirschhorn, M. Klannemark, et al., "The common PPAR $\gamma$ Pro12Ala polymorphism is associated with decreased risk of type 2 diabetes," Nature Genetics, vol. 26, no. 1, pp. 76-80, 2000.

[172] A. Dunaif, D. Scott, D. Finegood, B. Quintana, and R. Whitcomb, "The insulin-sensitizing agent troglitazone improves metabolic and reproductive abnormalities in the polycystic ovary syndrome," Journal of Clinical Endocrinology and Metabolism, vol. 81, no. 9, pp. 3299-3306, 1996.

[173] R. Azziz, D. Ehrmann, R. S. Legro, et al., "Troglitazone improves ovulation and hirsutism in the polycystic ovary syndrome: a multicenter, double blind, placebo-controlled trial," Journal of Clinical Endocrinology and Metabolism, vol. 86, no. 4, pp. 1626-1632, 2001.

[174] G. Ghazeeri, W. H. Kutteh, M. Bryer-Ash, D. Haas, and R. W. $\mathrm{Ke}$, "Effect of rosiglitazone on spontaneous and clomiphene citrate-induced ovulation in women with polycystic ovary syndrome," Fertility and Sterility, vol. 79, no. 3, pp. 562-566, 2003.

[175] A. Meirhaeghe and P. Amouyel, "Impact of genetic variation of PPAR $\gamma$ in humans," Molecular Genetics and Metabolism, vol. 83, no. 1-2, pp. 93-102, 2004.

[176] M. Hara, S. Y. Alcoser, A. Qaadir, K. K. Beiswenger, N. J. Cox, and D. A. Ehrmann, "Insulin resistance is attenuated in women with polycystic ovary syndrome with the Pro12Ala polymorphism in the ppary gene," Journal of Clinical Endocrinology and Metabolism, vol. 87, no. 2, pp. 772-775, 2002.
[177] S. Hahn, A. Fingerhut, U. Khomtsiv, et al., "The peroxisome proliferator activated receptor gamma Pro12Ala polymorphism is associated with a lower hirsutism score and increased insulin sensitivity in women with polycystic ovary syndrome," Clinical Endocrinology, vol. 62, no. 5, pp. 573579, 2005.

[178] E. C. Tok, A. Aktas, D. Ertunc, E. M. Erdal, and S. Dilek, "Evaluation of glucose metabolism and reproductive hormones in polycystic ovary syndrome on the basis of peroxisome proliferator-activated receptor (PPAR)- $\gamma 2$ Pro12Ala genotype," Human Reproduction, vol. 20, no. 6, pp. 15901595, 2005.

[179] S. Korhonen, S. Heinonen, M. Hiltunen, et al., "Polymorphism in the peroxisome proliferator-activated receptor- $\gamma$ gene in women with polycystic ovary syndrome," Human Reproduction, vol. 18, no. 3, pp. 540-543, 2003.

[180] M. Yilmaz, M. A. Ergün, A. Karakoç, et al., "Pro12Ala polymorphism of the peroxisome proliferator-activated receptor$\gamma$ gene in first-degree relatives of subjects with polycystic ovary syndrome," Gynecological Endocrinology, vol. 21, no. 4, pp. 206-210, 2005.

[181] M. Yilmaz, M. A. Ergün, A. Karakoç, E. Yurtçu, N. Çakir, and M. Arslan, "Pro12Ala polymorphism of the peroxisome proliferator-activated receptor- $\gamma$ gene in women with polycystic ovary syndrome," Gynecological Endocrinology, vol. 22, no. 6, pp. 336-342, 2006.

[182] F. Orio Jr., G. Matarese, S. Di Biase, et al., "Exon 6 and 2 peroxisome proliferator-activated receptor- $\gamma$ polymorphisms in polycystic ovary syndrome," Journal of Clinical Endocrinology and Metabolism, vol. 88, no. 12, pp. 5887-5892, 2003.

[183] Y. Wang, X. Wu, Y. Cao, L. Yi, H. Fan, and J. Chen, "Polymorphisms of the peroxisome proliferator-activated receptor- $\gamma$ and its coactivator- $1 \alpha$ genes in Chinese women with polycystic ovary syndrome," Fertility and Sterility, vol. 85, no. 5, pp. 1536-1540, 2006.

[184] F. Orio Jr., S. Palomba, T. Cascella, et al., "Lack of an association between peroxisome proliferator-activated receptor- $\gamma$ gene Pro12Ala polymorphism and adiponectin levels in the polycystic ovary syndrome," Journal of Clinical Endocrinology and Metabolism, vol. 89, no. 10, pp. 5110-5115, 2004.

[185] C. R. Milner, J. E. Craig, N. D. Hussey, and R. J. Norman, "No association between the -308 polymorphism in the tumour necrosis favor $\alpha$ (TNF $\alpha$ ) promoter region and polycystic ovaries," Molecular Human Reproduction, vol. 5, no. 1, pp. 5-9, 1999.

[186] W. Mao, L. Yu, and Y. Chen, "Study on the relationship between a polymorphism of tumor necrosis factor- $\alpha$ gene and the pathogenesis of polycystic ovary syndrome," Zhonghua Fu Chan Ke Za Zhi, vol. 35, no. 9, pp. 536-539, 2000.

[187] S. Korhonen, E.-L. Romppanen, M. Hiltunen, et al., "Lack of association between C-850T polymorphism of the gene encoding tumor necrosis factor- $\alpha$ and polycystic ovary syndrome," Gynecological Endocrinology, vol. 16, no. 4, pp. 271274, 2002.

[188] B. Peral, J. L. San Millán, R. Castello, P. Moghetti, and H. F. Escobar-Morreale, "Comment: the methionine 196 arginine polymorphism in exon 6 of the TNF receptor 2 gene (TNFRSF1B) is associated with the polycystic ovary syndrome and hyperandrogenism," Journal of Clinical Endocrinology and Metabolism, vol. 87, no. 8, pp. 3977-3983, 2002.

[189] M. Möhlig, J. Spranger, M. Osterhoff, et al., "The polycystic ovary syndrome per se is not associated with increased 
chronic inflammation," European Journal of Endocrinology, vol. 150, no. 4, pp. 525-532, 2004.

[190] H. F. Escobar-Morreale, R. M. Calvo, G. Villuendas, J. Sancho, and J. L. San Millán, "Association of polymorphisms in the interleukin 6 receptor complex with obesity and hyperandrogenism," Obesity Research, vol. 11, no. 8, pp. 987-996, 2003.

[191] D. Seto-Young, M. Paliou, J. Schlosser, et al., "Direct thiazolidinedione action in the human ovary: insulin-independent and insulin-sensitizing effects on steroidogenesis and insulinlike growth factor binding protein-1 production," Journal of Clinical Endocrinology and Metabolism, vol. 90, no. 11, pp. 6099-6105, 2005.

[192] D. Glintborg, R. K. Støving, C. Hagen, et al., "Pioglitazone treatment increases spontaneous growth hormone $(\mathrm{GH})$ secretion and stimulated GH levels in polycystic ovary syndrome," Journal of Clinical Endocrinology and Metabolism, vol. 90, no. 10, pp. 5605-5612, 2005.

[193] E. Jansen, J. S. E. Laven, H. B. R. Dommerholt, et al., "Abnormal gene expression profiles in human ovaries from polycystic ovary syndrome patients," Molecular Endocrinology, vol. 18, no. 12, pp. 3050-3063, 2004.

[194] J. R. Wood, V. l. Nelson-Degrave, E. Jansen, J. M. McAllister, S. Mosselman, and J. F. Strauss III, "Valproate-induced alterations in human theca cell gene expression: clues to the association between valproate use and metabolic side effects," Physiological Genomics, vol. 20, pp. 233-243, 2005.

[195] J. M. Fernández-Real and W. Ricart, "Insulin resistance and chronic cardiovascular inflammatory syndrome," Endocrine Reviews, vol. 24, no. 3, pp. 278-301, 2003.

[196] E. Diamanti-Kandarakis, C. Piperi, J. Spina, et al., "Polycystic ovary syndrome: the influence of environmental and genetic factors," Hormones (Athens, Greece), vol. 5, no. 1, pp. 17-34, 2006.

[197] G. S. Hotamisligil, P. Peraldi, A. Budavari, R. Ellis, M. F. White, and B. M. Spiegelman, "IRS-1-mediated inhibition of insulin receptor tyrosine kinase activity in TNF- $\alpha$ and obesity-induced insulin resistance," Science, vol. 271, no. 5249, pp. 665-668, 1996.

[198] H. F. Escobar-Morreale, R. M. Calvo, J. Sancho, and J. L. San Millán, "TNF- $\alpha$ and hyperandrogenism: a clinical, biochemical, and molecular genetic study," Journal of Clinical Endocrinology and Metabolism, vol. 86, no. 8, pp. 3761-3767, 2001.

[199] G. Villuendas, J. L. San Millán, J. Sancho, and H. F. EscobarMorreale, "The $-597 \mathrm{G} \rightarrow \mathrm{A}$ and $-174 \mathrm{G} \rightarrow \mathrm{C}$ polymorphisms in the promoter of the IL-6 gene are associated with hyperandrogenism," Journal of Clinical Endocrinology and Metabolism, vol. 87, no. 3, pp. 1134-1141, 2002.

[200] B. O. Yildiz, I. C. Haznedaroğlu, S. Kirazli, and M. Bayraktar, "Global fibrinolytic capacity is decreased in polycystic ovary syndrome, suggesting a prothrombotic state," Journal of Clinical Endocrinology and Metabolism, vol. 87, no. 8, pp. 38713875, 2002.

[201] P. Eriksson, B. Kallin, F. M. Van't Hooft, P. Bavenholm, and A. Hamsten, "Allele-specific increase in basal transcription of the plasminogen-activator inhibitor 1 gene is associated with myocardial infarction," Proceedings of the National Academy of Sciences of the United States of America, vol. 92, no. 6, pp. 1851-1855, 1995.

[202] E. Diamanti-Kandarakis, G. Palioniko, K. Alexandraki, A. Bergiele, T. Koutsouba, and M. Bartzis, "The prevalence of $4 \mathrm{G} 5 \mathrm{G}$ polymorphism of plasminogen activator ihibitor-1
(PAI-1) gene in polycystic ovarian syndrome and its association with plasma PAI-1 levels," European Journal of Endocrinology, vol. 150, no. 6, pp. 793-798, 2004.

[203] S. Nayak, P. A. Lee, and S. F. Witchel, "Variants of the type II $3 \beta$-hydroxysteroid dehydrogenase gene in children with premature pubic hair and hyperandrogenic adolescents," Molecular Genetics and Metabolism, vol. 64, no. 3, pp. 184-192, 1998.

[204] N. Moghrabi, I. A. Hughes, A. Dunaif, and S. Andersson, "Deleterious missense mutations and silent polymorphism in the human $17 \beta$-hydroxysteroid dehydrogenase 3 gene (HSD17B3)," Journal of Clinical Endocrinology and Metabolism, vol. 83, no. 8, pp. 2855-2860, 1998.

[205] R. S. Legro, D. R. Muhleman, D. E. Comings, R. A. Lobo, and B. W. Kovacs, "A dopamine D3 receptor genotype is associated with hyperandrogenic chronic anovulation and resistant to ovulation induction with clomiphene citrate in female hispanics," Fertility and Sterility, vol. 63, no. 4, pp. 779-784, 1995.

[206] M. Kahsar-Miller, L. R. Boots, and R. Azziz, "Dopamine D3 receptor polymorphism is not associated with the polycystic ovary syndrome," Fertility and Sterility, vol. 71, no. 3, pp. 436-438, 1999.

[207] S. P. Zhao, X. M. Tang, D. H. Shao, H. Y. Dai, and S. Z. Dai, "Association study between a polymorphism of aldosterone synthetase gene and the pathogenesis of polycystic ovary syndrome," Zhonghua Fu Chan Ke Za Zhi, vol. 38, no. 2, pp. 9497, 2003.

[208] M. Rajkhowa, J. A. Talbot, P. W. Jones, and R. N. Clayton, "Polymorphism of glycogen synthetase gene in polycystic ovary syndrome," Clinical Endocrinology, vol. 44, no. 1, pp. 85-90, 1996.

[209] M. Urbanek, Y. Du, K. Silander, et al., "Variation in resistin gene promoter not associated with polycystic ovary syndrome," Diabetes, vol. 52, no. 1, pp. 214-217, 2003.

[210] S. Heinonen, S. Korhonen, M. Hippelainen, M. Hiltunen, A. Mannermaa, and S. Saarikoski, "Apolipoprotein E alleles in women with polycystic ovary syndrome," Fertility and Sterility, vol. 75, no. 5, pp. 878-880, 2001.

[211] R. Azziz, "PCOS: a diagnostic challenge," Reproductive BioMedicine Online, vol. 8, no. 6, pp. 644-648, 2004.

[212] D. Gordon and S. J. Finch, "Factors affecting statistical power in the detection of genetic association," Journal of Clinical Investigation, vol. 115, no. 6, pp. 1408-1418, 2005.

[213] H. F. Escobar-Morreale, M. Luque-Ramírez, and J. L. San Millán, "The molecular-genetic basis of functional hyperandrogenism and the polycystic ovary syndrome," Endocrine Reviews, vol. 26, no. 2, pp. 251-282, 2005.

[214] M. Garg, M. Thamotharan, L. Rogers, S. Bassilian, W. N. P. Lee, and S. U. Devaskar, "Glucose metabolic adaptations in the intrauterine growth-restricted adult female rat offspring," American Journal of Physiology - Endocrinology and Metabolism, vol. 290, no. 6, pp. E1218-E1226, 2006. 


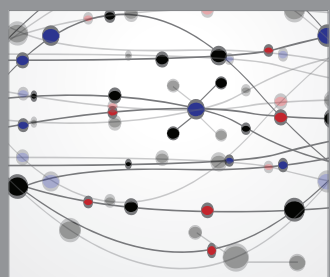

The Scientific World Journal
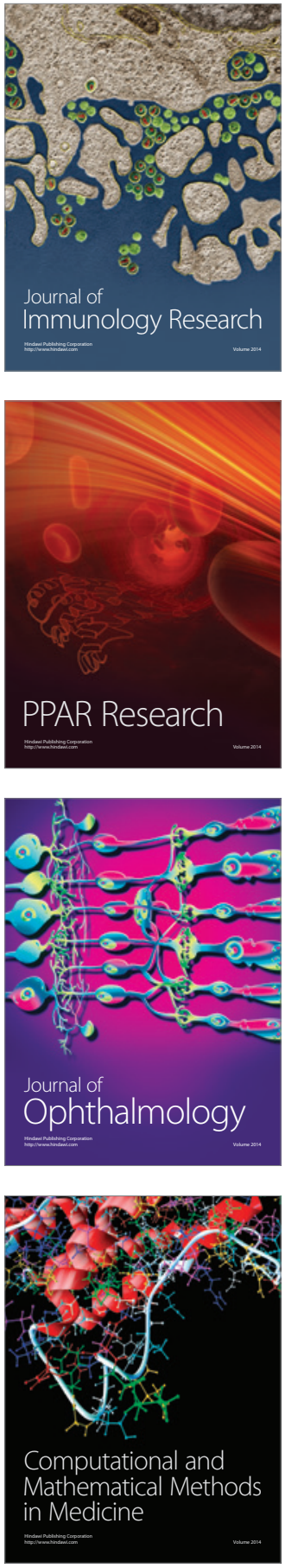

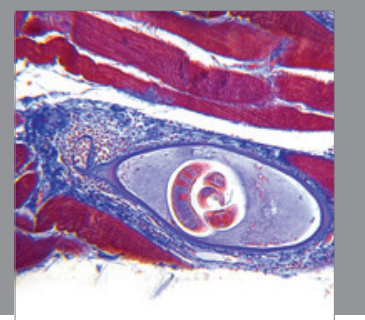

Gastroenterology

Research and Practice
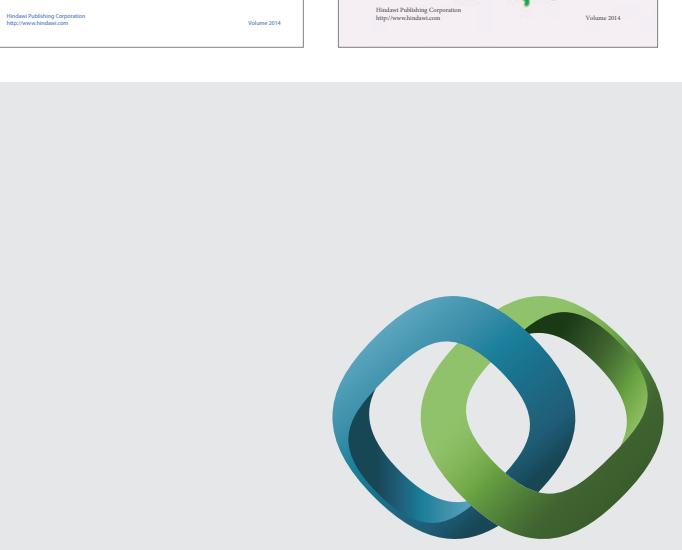

\section{Hindawi}

Submit your manuscripts at

http://www.hindawi.com
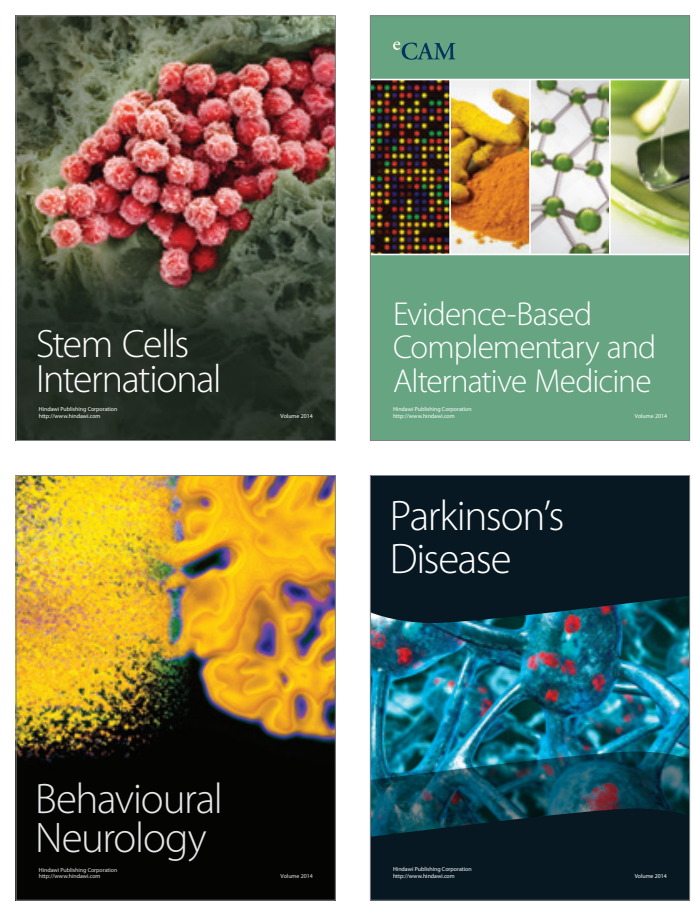

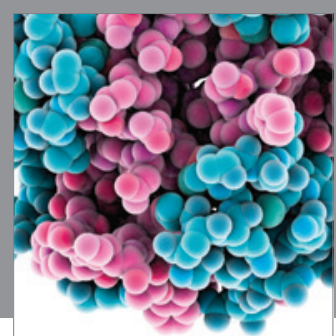

Journal of
Diabetes Research

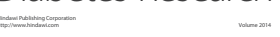

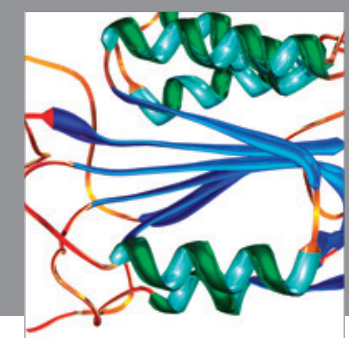

Disease Markers
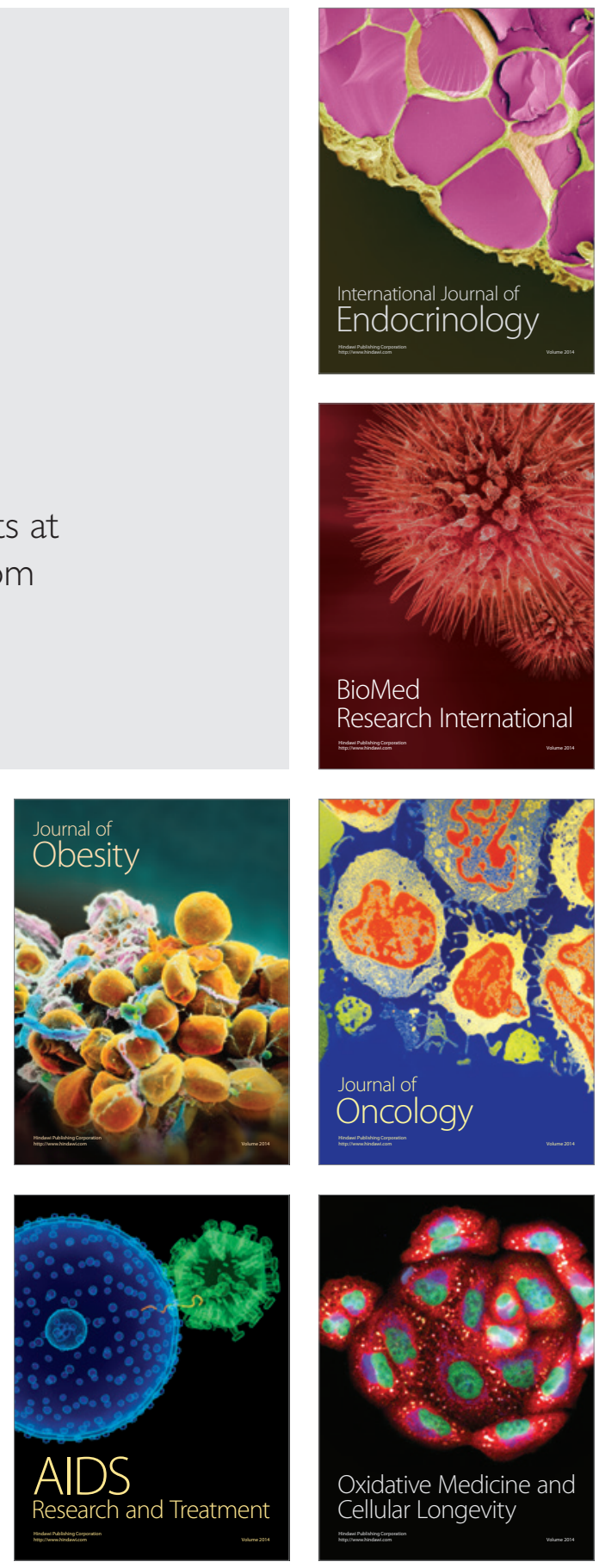